\title{
Ratiometric Near-Infrared Fluorescent Probes Based on Hemicyanine Dyes Bearing Dithioacetal and Formal Residues for $\mathrm{pH}$ Detection in Mitochondria
}

\author{
Yunnan Yan ${ }^{1,2}$, Yibin Zhang ${ }^{1, * \mathbb{D}}$, Shuai Xia ${ }^{1}$, Shulin Wan ${ }^{1}$, Tara Vohs ${ }^{1}$, Marina Tanasova ${ }^{1}$, Rudy L. Luck ${ }^{1, *(\mathbb{D})}$ \\ and Haiying Liu ${ }^{1, *}$ \\ 1 Department of Chemistry, Michigan Technological University, Houghton, MI 49931, USA; \\ zdyunnan@163.com (Y.Y.); shuaix@mtu.edu (S.X.); swan@mtu.edu (S.W.); tavohs@mtu.edu (T.V.); \\ mtanasov@mtu.edu (M.T.) \\ 2 College of Pharmaceutical Sciences, Gannan Medical University, Ganzhou 341000, China \\ * Correspondence: yibinz@mtu.edu (Y.Z.); rluck@mtu.edu (R.L.L.); hyliu@mtu.edu (H.L.)
}

check for updates

Citation: Yan, Y.; Zhang, Y.; Xia, S.; Wan, S.; Vohs, T.; Tanasova, M.; Luck, R.L.; Liu, H. Ratiometric

Near-Infrared Fluorescent Probes

Based on Hemicyanine Dyes Bearing Dithioacetal and Formal Residues for $\mathrm{pH}$ Detection in Mitochondria. Molecules 2021, 26, 2088. https:// doi.org/10.3390/molecules26072088

Academic Editors: Ivo Piantanida, René Csuk and Claus Jacob

Received: 5 March 2021

Accepted: 1 April 2021

Published: 6 April 2021

Publisher's Note: MDPI stays neutral with regard to jurisdictional claims in published maps and institutional affiliations.

Copyright: (c) 2021 by the authors. Licensee MDPI, Basel, Switzerland. This article is an open access article distributed under the terms and conditions of the Creative Commons Attribution (CC BY) license (https:// creativecommons.org/licenses/by/ $4.0 /)$.

\begin{abstract}
Ratiometric near-infrared fluorescent probes $\left(\mathbf{A H}^{+}\right.$and $\left.\mathbf{B} \mathbf{H}^{+}\right)$have been prepared for $\mathrm{pH}$ determination in mitochondria by attaching dithioacetal and formal residues onto a hemicyanine dye. The reactive formyl group on probe $\mathbf{B H}^{+}$allows for retention inside mitochondria as it can react with a protein primary amine residue to form an imine under slightly basic $\mathrm{pH}$ 8.0. Probes $\mathbf{A H}^{+}$and $\mathbf{B H}^{+}$display ratiometric fluorescent responses to $\mathrm{pH}$ changes through the protonation and deprotonaton of a hydroxy group in hemicyanine dyes with experimentally determined $\mathrm{pKa}$ values of 6.85 and 6.49 , respectively. Calculated $\mathrm{p} K_{\mathrm{a}}$ values from a variety of theoretical methods indicated that the $\mathrm{SMD}_{\mathrm{BONDI}}$ method of accounting for solvent and van der Waals radii plus including a water molecule located near the site of protonation produced the closest overall agreement with the experimental values at 7.33 and 6.14 for $\mathbf{A H}^{+}$and $\mathbf{B H}^{+}$respectively.
\end{abstract}

Keywords: near-infrared fluorescence; ratiometric imaging; $\mathrm{pH}$; mitochondria; fluorescent probe

\section{Introduction}

Mitochondria are small subcellular organelles that generate adenosine triphosphate (ATP) to power various cell functions in all eukaryotic cells [1-4]. Mitochondria also control homeostasis and redox signaling and regulate cell apoptosis and death [1-4]. An alkaline $\mathrm{pH} \approx 8.0$ is essential in mitochondria to sustain the proton motive potential during the synthesis of ATP [5,6]. Effective detections of mitochondrial $\mathrm{pH}$ changes provide an insightful understanding of mitochondrial physiology and pathology [7]. Many fluorescent probes have been developed for monitoring mitochondrial $\mathrm{pH}$ and some of these feature excellent sensitivity and high three-dimensional and temporal resolution [7-9]. Specific targeting of mitochondria has been achieved by employing electrostatic interactions of positively charged fluorescent probes, such as rhodamine or cyanine dyes, with the potentially negative internal membranes of mitochondria [7-9]. Another strategy to position dyes within mitochondria consisted of designing a hemicyanine dye to covalently link with mitochondrial proteins through a direct displacement of the reactive chlorine group on the fluorophore [10].

It is well-known that the formyl group easily reacts with primary amines to form imine derivatives as Schiff bases [11-15]. For this reason, we developed a reactive ratiometric near-infrared fluorescent probe $\left(\mathbf{B H}^{+}\right)$for $\mathrm{pH}$ detection in mitochondria by attaching a formyl group to a hemicyanine dye in order to prevent the probe from diffusing away from mitochondria. We also contrast results with a ratiometric fluorescent probe bearing a thioacetal residue $\left(\mathrm{AH}^{+}\right)$, which could be hydrolyzed in cells, resulting in covalent linking to proteins. Ratiometric near-infrared fluorescent probes have desirable advantages such 
as near-infrared imaging to achieve deep tissue penetration, low photodamage to cells, and less biological sample autofluorescence. Our probes also possess self-calibration capability with two emissions to overcome systematic errors of intensity-based fluorescent probes produced by excitation light fluctuation, probe concentration changes, uneven distribution, and compartmental localization [16-24]. Both $\mathbf{A H}^{+}$and $\mathbf{B} \mathbf{H}^{+}$probes (Scheme 1) show ratiometric fluorescent probes to $\mathrm{pH}$ changes with the largest bathochromic shifts of $38 \mathrm{~nm}$ and $59 \mathrm{~nm}$ based on the protonation and deprotonation of a hydroxy group attached to the hemicyanine dyes, respectively.
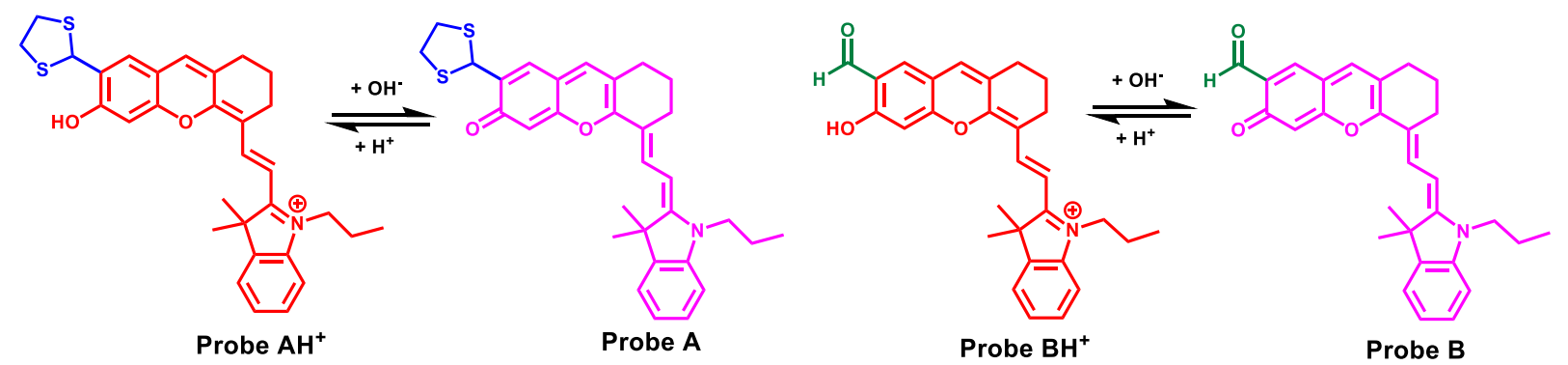

Scheme 1. Chemical structures of ratiometric fluorescent probes bearing thioacetal and formyl residues for $\mathrm{pH}$ detection in mitochondria.

\section{Results and Discussion}

\subsection{Probe Design and Synthesis}

The fact that formyl and dithioacetal groups chemically react with amine residues has been widely used for the covalent modification of proteins. We sought to utilize this property to prevent the fluorescent probe from diffusing out of mitochondria and designed probes $\mathbf{A H}^{+}$and $\mathbf{B H}^{+}$that carry dithioacetal and formyl moieties, respectively, on the hemicyanine dye. We envisioned that the formyl moiety could directly interact with proteins upon localization of the probe in mitochondria. On the other hand, the dithioacetal could hydrolyze to yield a reactive formyl group in cells for an analogous covalent linking with proteins. The chemical synthesis of these probes started with protecting an aldehyde group of 2,4-dihydroxybenzaldehyde (1) by converting it into a dithioacetal residue, yielding 4-(1,3-dithiolan-2-yl)benzene-1,3-diol (2). Reacting compound 2 with cyanine dye (IR-780) (3) in DMF under basic conditions generated a hemicyanine dye bearing a dithioacetal residue (probe $\mathrm{AH}^{+}$). Deprotection of the dithioacetal residue in probe $\mathrm{AH}^{+}$under an acidic environment produced the hemicyanine dye bearing a formyl group (probe $\mathbf{B H}^{+}$) (Scheme 2).

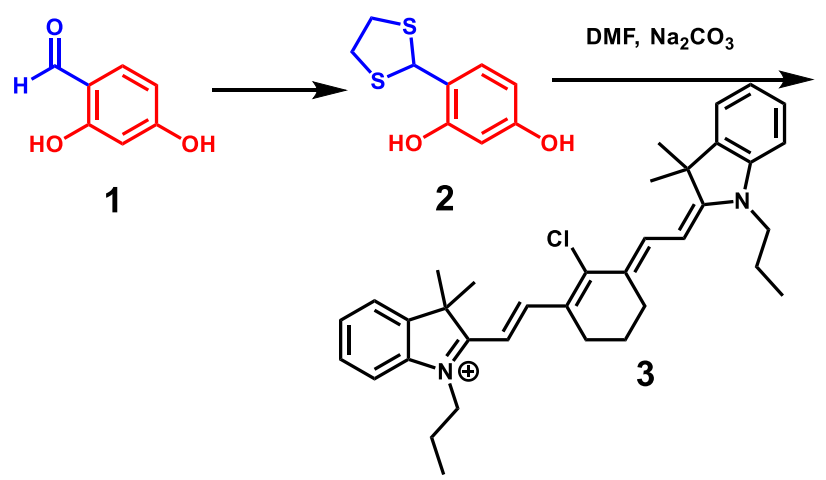

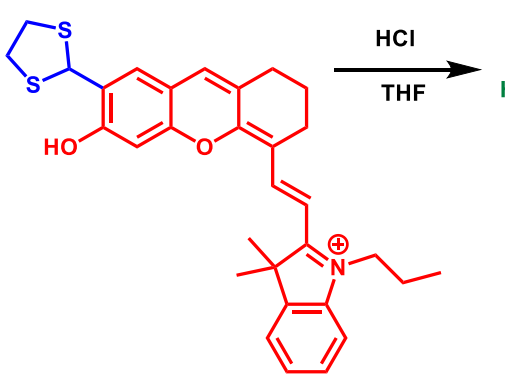

Probe $\mathrm{AH}^{+}$<smiles>CCCN1C(/C=C/C2=C3Oc4cc(O)c(C=O)cc4C=C3CCC2)=C(C)C(C)(C)c2ccccc21</smiles>

Probe $\mathrm{BH}^{+}$

Scheme 2. Synthetic approach to prepare fluorescent probes bearing thioacetal and formyl residues for $\mathrm{pH}$ detection in mitochondria. 


\subsection{Optical Responses of Probes $\mathbf{A H}^{+}$and $\mathbf{B H}^{+}$to $\mathrm{pH}$ Changes}

UV-vis studies of probes $\mathbf{A H}^{+}$and $\mathbf{B H}^{+}$show that both probes are sensitive to changes in $\mathrm{pH}$ level. At $\mathrm{pH} 4.0$, probe $\mathrm{AH}^{+}$shows two absorption peaks at $611 \mathrm{~nm}$ and $658 \mathrm{~nm}$ (Figure 1, left). A gradual increase of $\mathrm{pH}$ from 4.0 to 10.1 causes a significant red shift in absorption with a broad absorption peak appearing at $700 \mathrm{~nm}$. The observed shift can be attributed to the stabilization of a negatively charged hemicyanine portion of the dye due to the deprotonation of the hydroxyl group on the hemicyanine dye under basic conditions. Probe $\mathbf{B H}^{+}$exhibits a main absorption peak at $586 \mathrm{~nm}$, and a shoulder peak at $630 \mathrm{~nm}$ at $\mathrm{pH} 4.0$ (Figure 1, right). Gradual increases in $\mathrm{pH}$ result in considerable red shifts to two absorption peaks at $630 \mathrm{~nm}$ and $684 \mathrm{~nm}$ at $\mathrm{pH}$ 10.1. The changes in absorption for probe $\mathbf{B H}^{+}$can be also observed visually as the color of the solution changes from purple to blueish green with increasing $\mathrm{pH}$ (Figure 2).

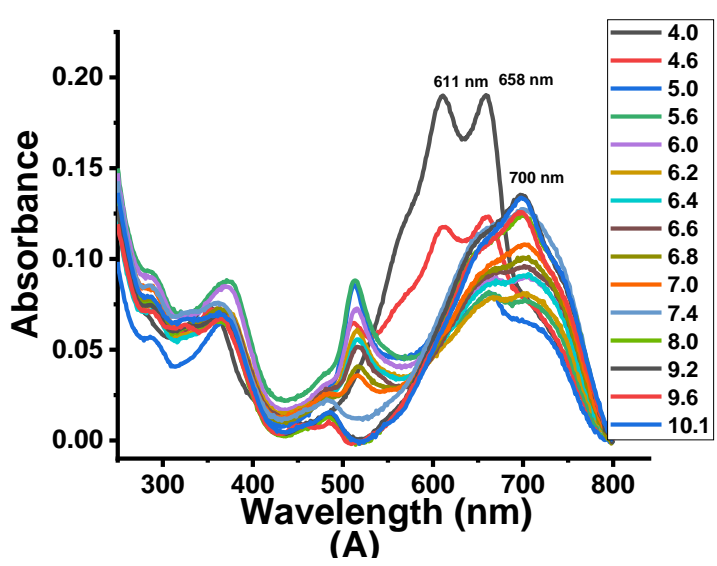

Figure 1. Absorption spectra of $10 \mu \mathrm{M}$ probes $\mathbf{A H}^{+}(\mathbf{A})$ and $\mathbf{B H}^{+}(\mathbf{B})$ in PBS buffers with $\mathrm{pH}$ changes from 4.0 to 10.1 , respectively.

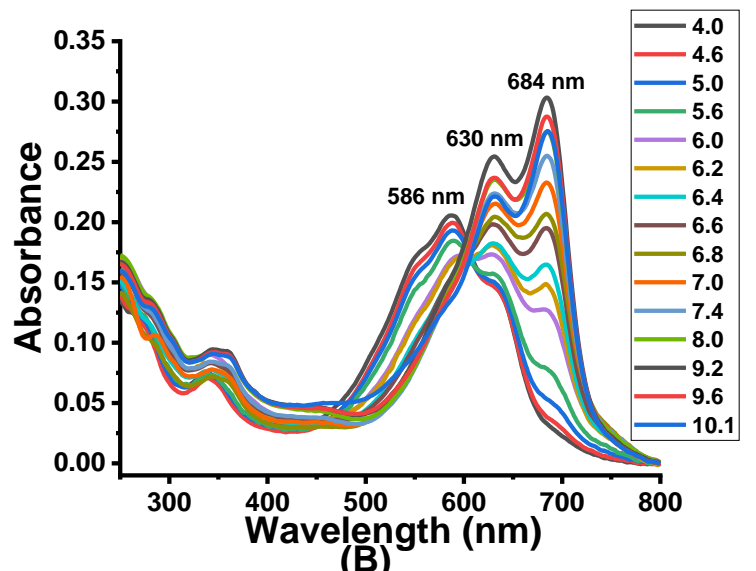

(B)

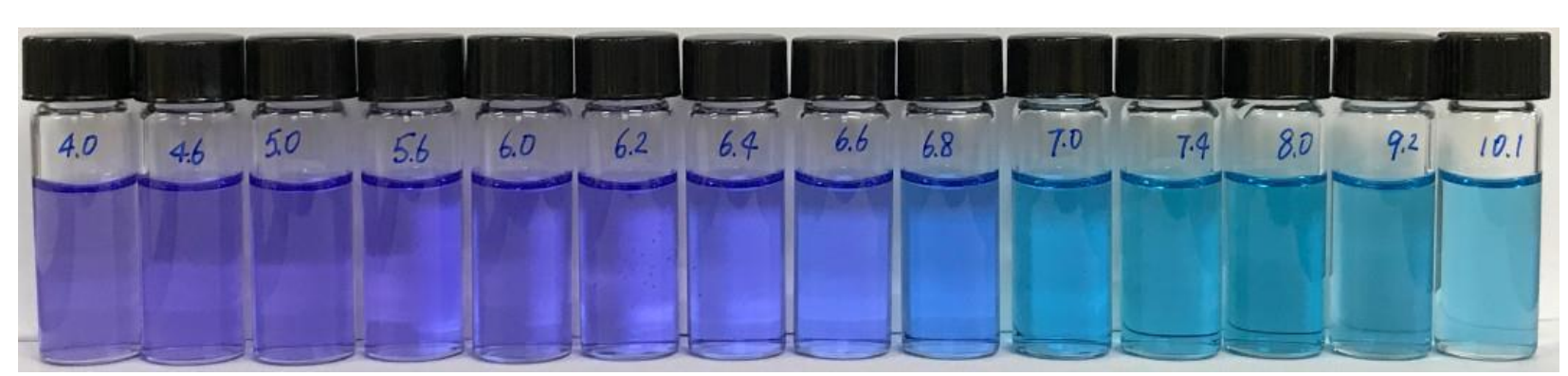

Figure 2. Photos of $10 \mu \mathrm{M}$ probe ${ }^{+} \mathbf{A H}^{+}$in different $\mathrm{pH}$ PBS buffers where $\mathrm{pH}$ values were marked in the vials above.

Standard $\mathrm{pH}$ titrations of the probes were also conducted to assess fluorescence changes. At $\mathrm{pH} 4.0$, probe $\mathrm{AH}^{+}$shows a fluorescence peak at $680 \mathrm{~nm}$ at $\mathrm{pH} 4.0$ (Figure 3, left). Gradual increase of $\mathrm{pH}$ from 4.0 to 10.1 results in decreased fluorescence emission at $680 \mathrm{~nm}$ and increased emission at $718 \mathrm{~nm}$ with an overall bathochromic shift of $38 \mathrm{~nm}$ (Figure 3, left). The experimental $\mathrm{pK}_{\mathrm{a}}$ value for $\mathbf{A H}^{+}$is 6.85 (Figure 4). The quantum yields measured for $\mathbf{A H}^{+}$at $\mathrm{pH} 4.1$ and 9.2 are $0.06 \%$ and $0.27 \%$, respectively, (Table 1). Alterations in solution $\mathrm{pH}$ also impacted fluorescence for probe $\mathbf{B} \mathbf{H}^{+}$. At $\mathrm{pH}$ 4.0, probe $\mathbf{B} \mathbf{H}^{+}$displays a fluorescence peak at $667 \mathrm{~nm}$. Changing the $\mathrm{pH}$ of the solution from 4.0 to 10.1 induced a ratiometric red shift in fluorescence emission to $715 \mathrm{~nm}$, with an overall bathochromic shift of $48 \mathrm{~nm}$. The experimental $\mathrm{pK}$ a value for $\mathbf{B} \mathbf{H}^{+}$is 6.49 (Figure 4). In comparison to $\mathbf{A H}^{+}$, probe $\mathbf{B H}^{+}$is slightly blue-shifted in fluorescence due to the electron-withdrawing nature of the formyl group (Figure 3). The quantum yields measured for probe $\mathbf{B H}^{+}$at $\mathrm{pH} 4.1$ and 
9.2 are $1.9 \%$ and $12.3 \%$, respectively (Table 1). It is noteworthy that both probes behave as fluorescent $\mathrm{pH}$ sensors as is evident from the experimentally-observed reversible red or blue shifts due to the reversible protonation and deprotonation of the hemicyanine dye upon $\mathrm{pH}$ changes as the probes show satisfactory reversibility between $\mathrm{pH} 10.0$ and $\mathrm{pH} 4.0$ (Figure 5).

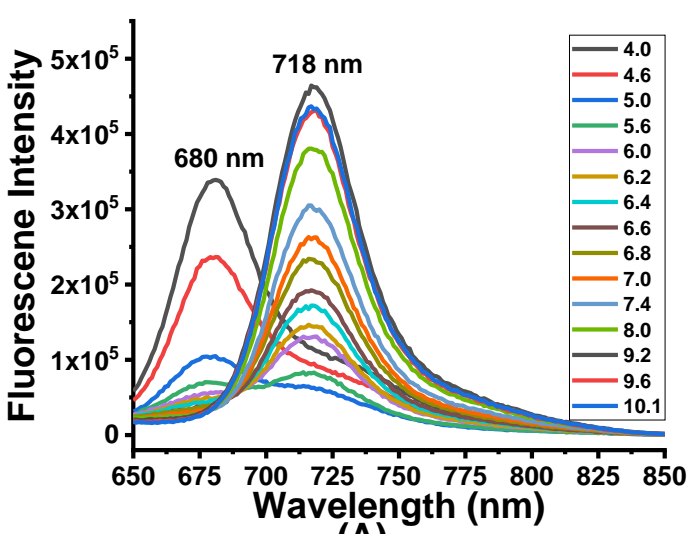

(A)

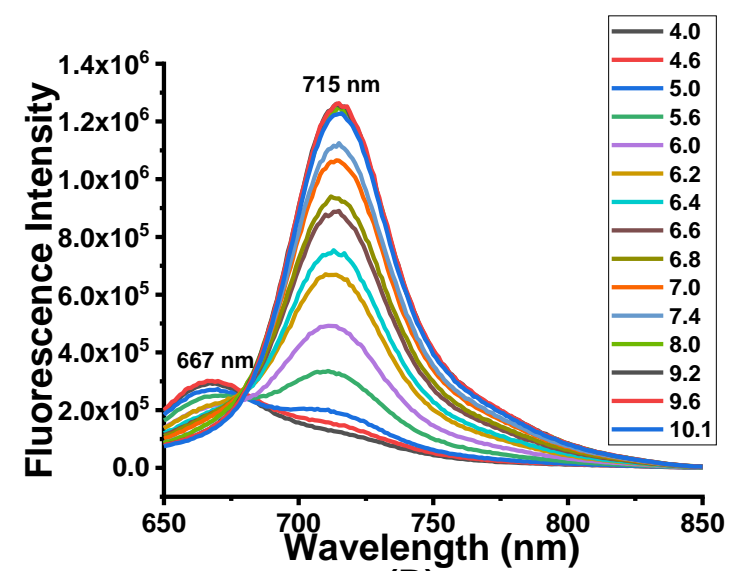

(B)

Figure 3. Fluorescence spectra of $10 \mu \mathrm{M}$ probes $\mathbf{A H}^{+}(\mathbf{A})$ and $\mathbf{B H}^{+}(\mathbf{B})$ in buffers with $\mathrm{pH}$ changes from 4.0 to 10.1 under excitation at $630 \mathrm{~nm}$.

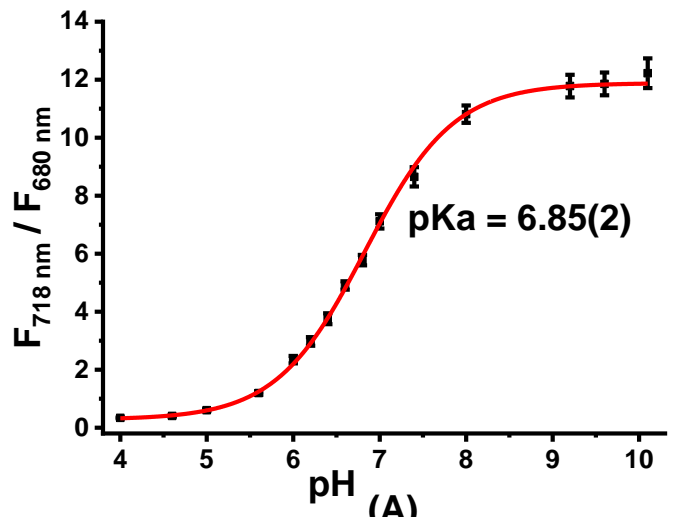

(A)

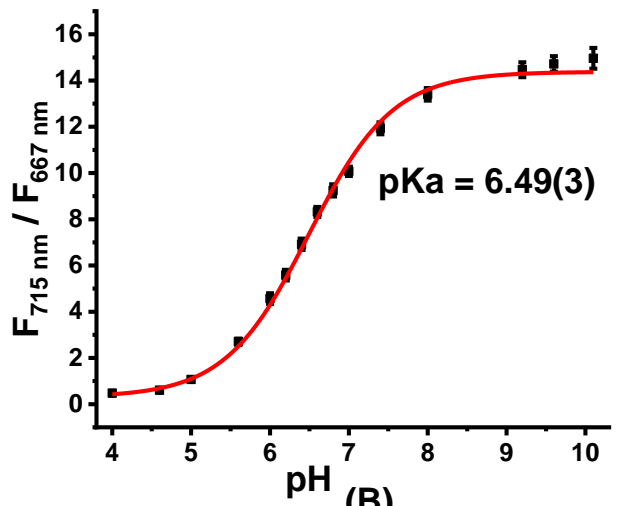

(B)

Figure 4. Fluorescence ratio changes of probes $\mathbf{A H}^{+}(\mathbf{A})$ and $\mathbf{B H}^{+}(\mathbf{B})$ versus $\mathrm{pH}$ changes from 4.0 to 10.1 under excitation at $630 \mathrm{~nm}$.
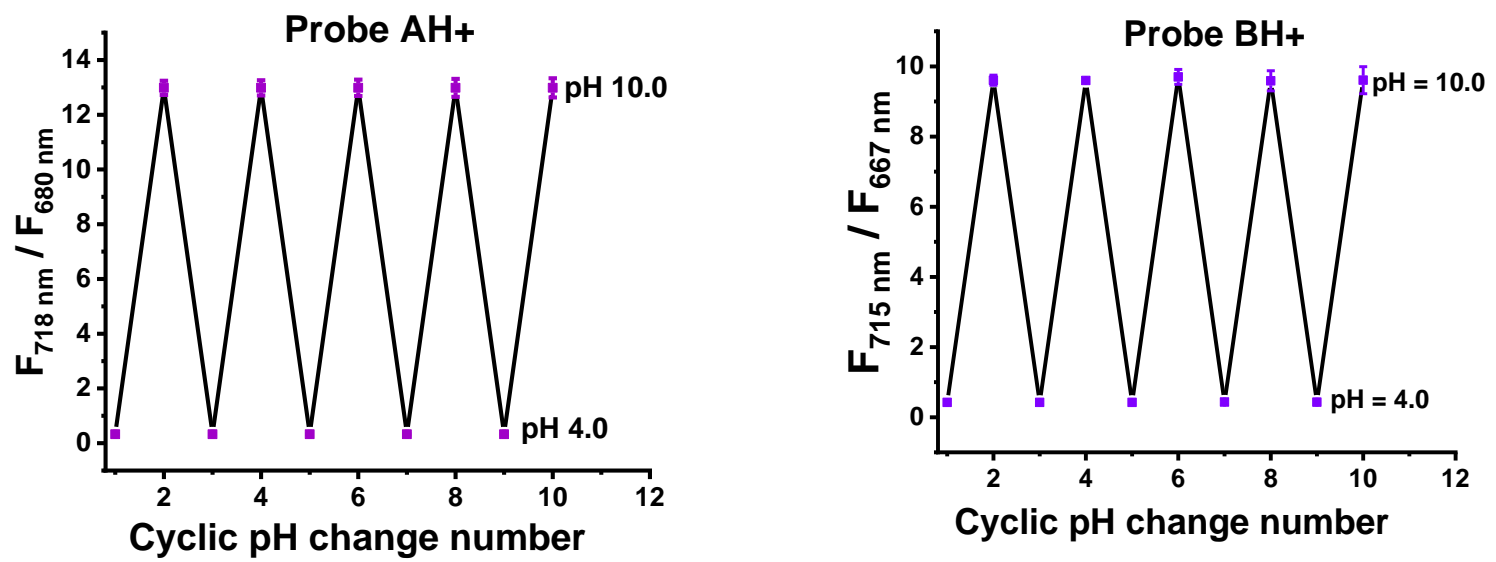

Figure 5. Fluorescence ratio changes of $10 \mu \mathrm{M}$ probes $\mathbf{A H}^{+}$(left) and $\mathbf{B H}^{+}$(right) versus cyclic $\mathrm{pH}$ changes from 4.0 to 10.0 or 10.0 to 4.0 . 
Table 1. Photophysical data of the probes.

\begin{tabular}{|c|c|c|c|c|c|c|c|}
\hline Probe & $\mathrm{pH}$ & $\mathrm{Abs}_{\max }(\mathrm{nm})$ & $\operatorname{Em}_{\max }(\mathrm{nm})$ & $\varepsilon\left(10^{5} \mathrm{M}^{-1} \mathrm{~cm}^{-1}\right)$ & $\Phi f$ & $\Delta \lambda_{\mathrm{fl}}(\mathrm{nm})$ & $\mathrm{p} K_{\mathrm{a}}$ \\
\hline \multirow{2}{*}{$\mathrm{AH}^{+}$} & 4.0 & 658 & 680 & 0.21 & 0.06 & \multirow{2}{*}{22} & \multirow{2}{*}{6.85} \\
\hline & 9.2 & 701 & 718 & 0.17 & 0.27 & & \\
\hline \multirow{2}{*}{$\mathrm{BH}^{+}$} & 4.0 & 586 & 667 & 0.42 & 1.9 & \multirow{2}{*}{81} & \multirow{2}{*}{6.49} \\
\hline & 9.2 & 684 & 715 & 0.36 & 12.3 & & \\
\hline
\end{tabular}

\subsection{Theoretical Results}

We further employed computational models to assess the $\mathrm{pH}$-induced geometric changes and the nature of the electronic transitions, and to calculate $\mathrm{p} K_{\mathrm{a}}$ values for both probes. For $\mathbf{A}, \mathbf{A H}^{+}, \mathbf{B}$, and $\mathbf{B H}^{+}$, stable converged geometries in almost completely planar conformations of the pseudo-rhodamine and hemicyanine moieties were obtained (Figures S1, S4, S7, and S10). This planarity resulted in a complete delocalization of the $\pi$-orbitals, with the apparent energy transition (Figure 6) between protonated and deprotonated forms. In all cases, this main transition consisted of the delocalization of electronic density from LCAO-HOMO to LCAO-LUMO upon deprotonation of the hydroxyl moiety. We found the calculated (Figures S2, S5, S8, and S11) and experimental absorption values to be in good agreement for $\mathbf{B}(0.18 \mathrm{eV})$ and $\mathbf{B H}^{+}(0.23 \mathrm{eV})$ probes (within the expected $0.20-0.25 \mathrm{eV}$ range [25]) but they were off for $\mathbf{A}(0.29 \mathrm{eV})$ and $\mathbf{A H}^{+}(0.35 \mathrm{eV})$ probes. Calculations also identified H-bonding between the dithioacetal and hydroxyl functionalities for $\mathrm{AH}^{+}$that could contribute to the appearance of the red-shifted transition for $\mathrm{AH}^{+}$at low $\mathrm{pH}(700 \mathrm{~nm}$ shoulder, Figure 1) and also influence the equilibrium between the protonated and deprotonated $\mathrm{OH}$ group. Analogous $\mathrm{H}$-bonding between the carbonyl and $\mathrm{OH}$, although not detected through calculations, could contribute to the shoulder in the UV absorption of $\mathbf{B H}^{+}$.

Given the plethora of functional and basis set combinations available today, calculating $\mathrm{p} K_{\mathrm{a}}$ values represents a challenging task. However, recent publications have suggested a more directed route to accomplish these calculations. The nature of the calculation involves getting the values listed in Equation (1), where $G^{*}$ aq refers to the calculated standard free energies of the deprotonated and protonated species in solution and $G^{*}{ }_{a q}\left(\mathrm{H}^{+}\right)=-270.30 \mathrm{kcal} / \mathrm{mol}$ [26]. The bases for the nature of the calculation have been described previously for carboxylic acids, amines, and thiols [27].

$$
\mathrm{pKa}=\left[\mathrm{G}_{a q}^{*}\left(\mathrm{~A}^{-}\right)-\mathrm{G}_{a q}^{*}\left(\mathrm{AH}^{+}\right)+\mathrm{G}_{a q}^{*}\left(\mathrm{H}^{+}\right)\right] /(2.303 \times \mathrm{RT})
$$

In order to derive the $\mathrm{p} K_{\mathrm{a}}$ values of alcohols, in addition to the utilization of the SMD method [28], it was suggested to model an $\mathrm{H}_{2} \mathrm{O}$ adduct hydrogen-bonded to the alcohol (Figure 7) [29]. We conducted calculations on these models and the data are summarized in Table 2. The calculations based on the IEF-PCM (the inclusion of a dielectric medium) model of aqueous solvation afforded a reasonable $\mathrm{p} K_{\mathrm{a}}=6.37$ value for probe $\mathrm{AH}^{+}$that is comparable to the experimental value of 6.85. However, for probe $\mathbf{B H}^{+}$, a significant difference in values ( 0.264 calculated vs. 6.40 experimental) was observed. 

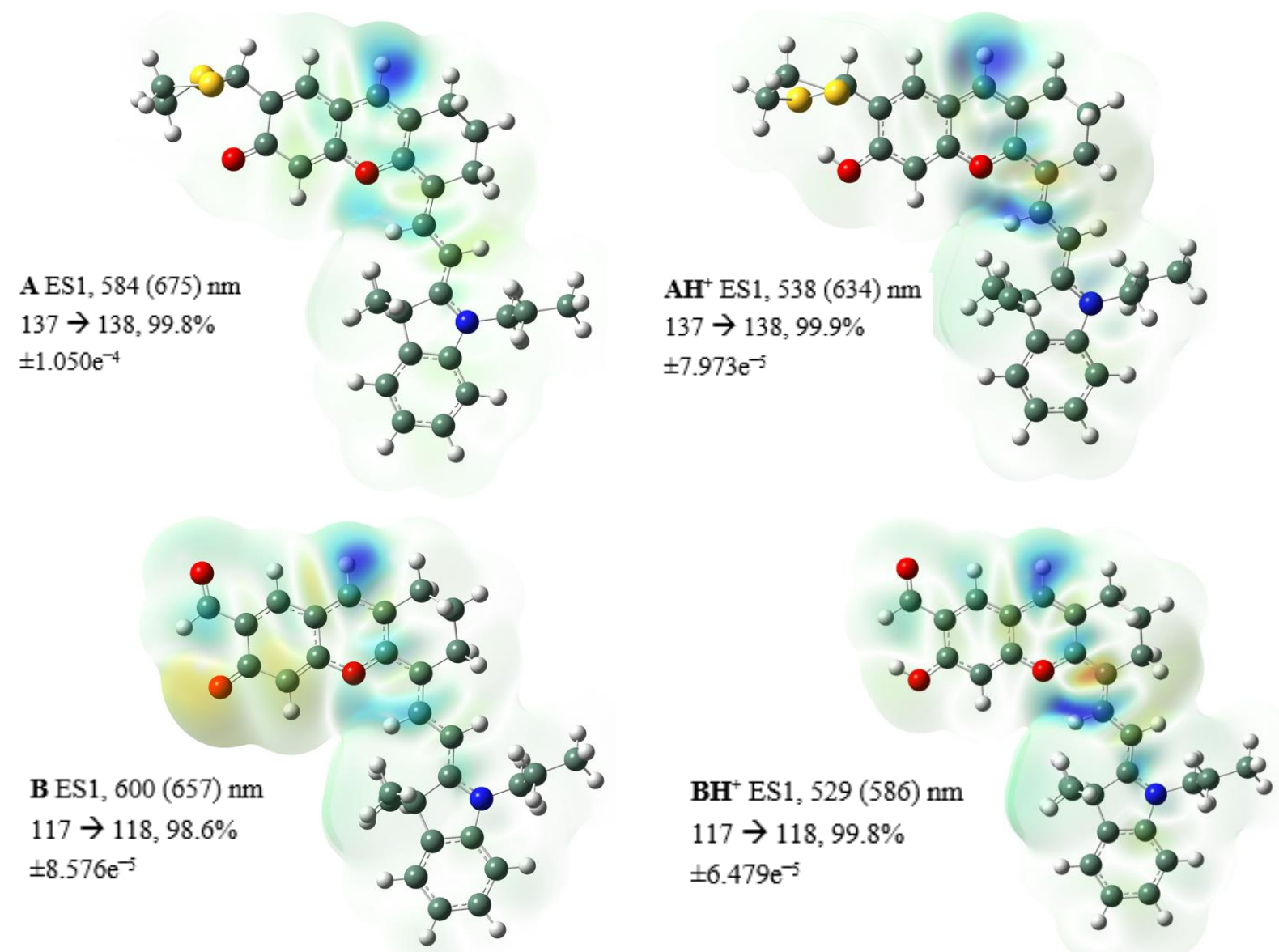

Figure 6. Illustrations of the current density difference as isosurfaces of the probes $\mathbf{A}$ and $\mathbf{B}$ and their protonated forms, $\mathbf{A H}^{+}$and $\mathbf{B H}^{+}$, as indicated for the excited states (ES) and the calculated (and experimental) wavelengths. The composition of specific ES and percentage contributions are indicated. The numerical range values for the color scale are also listed for each drawing. Drawings of the numbered MOs are available in the Supporting Information.
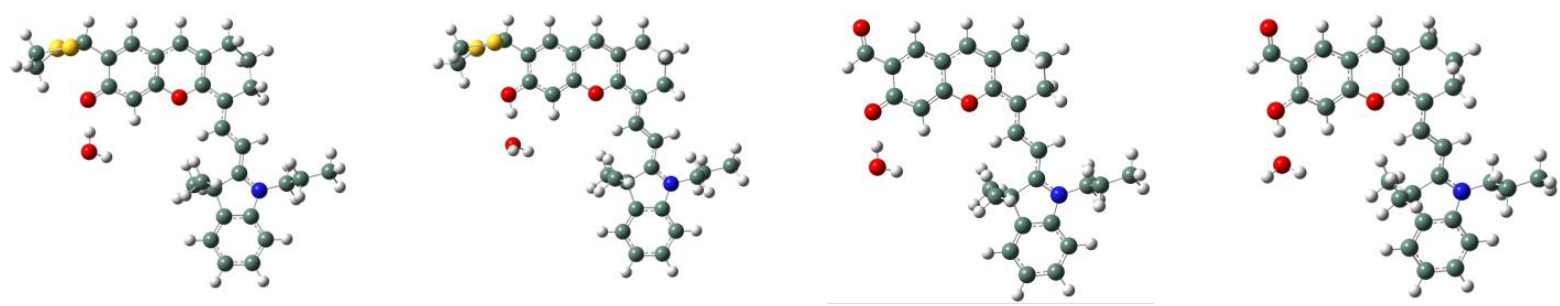

Figure 7. GaussView [30] drawings of the water molecule near the $\mathrm{OH}$ group for probes $\mathbf{A}, \mathbf{A H}{ }^{+}, \mathbf{B}$, and $\mathbf{B H}^{+}$(left to right with the $\mathrm{O}_{\text {probe }} \cdots \mathrm{O}_{\text {water }}$ separation at $2.648,2.659,2.667$ and $2.637 \AA$ respectively).

Table 2. Calculated $\mathrm{pKa}$ values for the probes.

\begin{tabular}{|c|c|c|c|c|c|c|c|c|}
\hline Probe & Experimental & IEF-PCM $^{\text {a }}$ & $\mathrm{SMD}^{\mathrm{b}}$ & $\operatorname{SMD}^{c}\left(\mathrm{H}_{2} \mathrm{O}\right)^{d}$ & Bondi & Bondi $\left(\mathrm{H}_{2} \mathrm{O}\right)$ & SAS & $\mathrm{SAS}\left(\mathrm{H}_{2} \mathrm{O}\right)$ \\
\hline $\mathrm{AH}^{+}$ & 6.85 & 6.37 & 8.52 & $8.29(8.66)$ & 8.54 & 7.33(7.57) & 9.64 & $8.60(9.76)$ \\
\hline $\mathrm{BH}^{+}$ & 6.49 & 0.26 & 6.48 & 6.27 & 5.81 & 6.14 & 7.60 & 6.92 \\
\hline
\end{tabular}

${ }^{\mathrm{a}}$ reference $[28,31]{ }^{\mathrm{b}}$ reference [28]. ${ }^{\mathrm{c}}$ reference [29]. ${ }^{\mathrm{d}}$ With S.H intramolecular interaction preserved. 
Based on previous reports, we performed calculations using the SMD variant of solvation (i.e., intrinsic Coulomb radii), including $\mathrm{SMD}_{\text {Bondi }}$ (intermolecular van der Waals radii [32]) and $\mathrm{SMD}_{\mathrm{SSAS}}$ (a scaled solvent-accessible surface) [27]. As listed in Table 2, $\mathrm{p} K_{\mathrm{a}}$ values of $8.52,8.54$, and 9.64 were calculated for probe $\mathbf{A H}^{+}$for the three methods, respectively. Using the same methods, the $\mathrm{p} K_{\mathrm{a}}$ values of $6.48,5.81$, and 7.60 were calculated for the $\mathbf{B H}^{+}$probe. In this case, a close correlation between the calculated and experimental (6.49) $\mathrm{p} K_{\mathrm{a}}$ values was observed for the $\mathbf{B} \mathbf{H}^{+}$probe but not for the $\mathbf{A H}^{+}$probe. Considering the shared H-bonding between the hydroxyl and dithioacetal moieties calculated for $\mathbf{A H}^{+}$, it is plausible that the discrepancy in $\mathrm{p} K_{\mathrm{a}}$ values for $\mathbf{A H}^{+}$arise due to the large errors in calculating the $\mathrm{p} K_{\mathrm{a}}$ values ( $\sim 6 \mathrm{p} K_{\mathrm{a}}$ units) for thiols using this method [27]. As a next step, we calculated $\mathrm{p} K_{\mathrm{a}}$ values after including a hydrogen-bonded water molecule near the hydroxyl group (Figure 7) [29]. Similar to previous calculations, a good agreement with experimental data was observed for $\mathbf{B H}^{+}$(calculated $\mathrm{p} K_{\mathrm{a}}$ values of $6.27,6.14$, and 6.92). For $\mathrm{AH}^{+}$, a reasonable correlation with the experimental $\mathrm{p} K_{\mathrm{a}}$ value was observed using the $\mathrm{SMD}_{\text {Bondi }}$ method (Table 2, Bondi $\left(\mathrm{H}_{2} \mathrm{O}\right)$ ). This agreement may pertain to the additional $\mathrm{H}$-bonding between the added water molecule and a lone pair on the hydroxyl's $\mathrm{O}$ atom (Figure S13 and Tables S33-S35), which would essentially mimic the partially-solvated $\mathrm{OH}$ bond within $\mathrm{AH}^{+}$. Overall, the $\mathrm{SMD}_{\text {Bondi }}$ method, with one water molecule included, was able to provide a close correlation with experimental $\mathrm{p} K_{\mathrm{a}}$ values, owing to the inclusion of a solvation factor. This would suggest that this type of model could serve as a useful starting point for theoretical $\mathrm{pKa}$ calculations on structurally similar and related molecules.

\subsection{Assessing $\mathrm{H}^{+}$Specificity of Probes $\mathbf{A H}^{+}$and $\mathbf{B H}^{+}$}

In order to evaluate the probe selectivity to $\mathrm{pH}$ over other potential interferents, the fluorescence spectra of the probes were recorded in the presence of various cations, anions, and amino acids at the physiological conditions ( $\mathrm{pH} 7.4)$. We found that cations such as $\mathrm{K}^{+}$, $\mathrm{Mg}^{2+}, \mathrm{Al}^{3+}, \mathrm{Ba}^{2+}, \mathrm{Fe}^{3+}, \mathrm{Co}^{2+}, \mathrm{Ni}^{2+}, \mathrm{Sn}^{4+}, \mathrm{Cu}^{2+}, \mathrm{Zn}^{2+}, \mathrm{Cd}^{2+}, \mathrm{Hg}^{2+}, \mathrm{Mn}^{2+}, \mathrm{Cr}^{3+}, \mathrm{Pb}^{2+}$, and $\mathrm{Fe}^{2+}$ (Figure 8), and anions such as $\mathrm{Cl}^{-}, \mathrm{CO}_{3}{ }^{2-}, \mathrm{HCO}_{3}{ }^{-}, \mathrm{SO}_{4}{ }^{2-}, \mathrm{SO}_{3}{ }^{2-}, \mathrm{HSO}_{3}{ }^{-}, \mathrm{NO}_{3}{ }^{-}$, $\mathrm{PO}_{4}{ }^{3-}$ and $\mathrm{S}_{2} \mathrm{O}_{3}{ }^{2-}$ do not cause any significant fluorescence changes in probe fluorescence (Figure 9). Probe fluorescence was also independent of the presence of amino acids (DLcysteine, DL-homocysteine, DL-alanine, DL-arginine, DL-leucine, DL-tyrosine, glutamic acid, glycine) and glutathione (GSH) (Figure 10). These results confirmed that the probes possess good selectivity to $\mathrm{pH}$ and suggested that probes are useful as $\mathrm{pH}$ sensors in a complex biological environment.
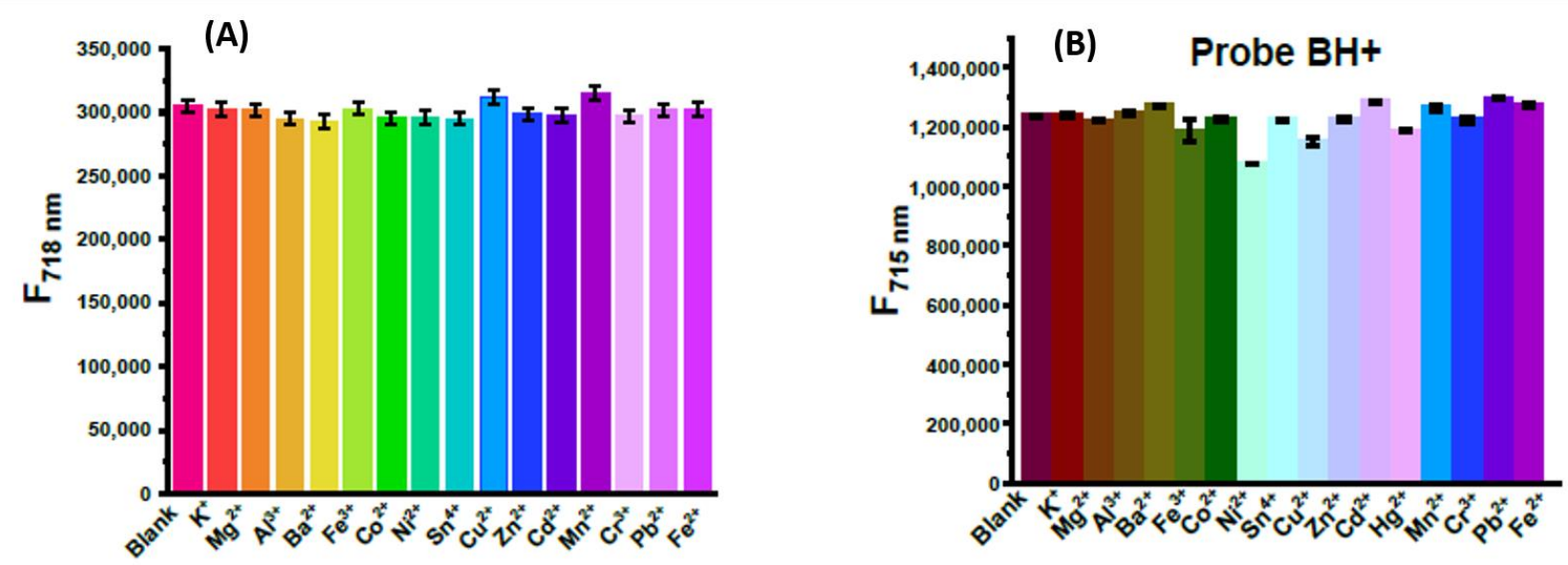

Figure 8. Fluorescence intensities of $10 \mu \mathrm{M}$ probes $\mathbf{A H}^{+}(\mathbf{A})$ and probe $\mathbf{B H}^{+}(\mathbf{B})$ in the absence and presence of different cations $(200 \mu \mathrm{M})$ in $\mathrm{pH} 7.4$ buffers under excitation at $635 \mathrm{~nm}$, respectively. 

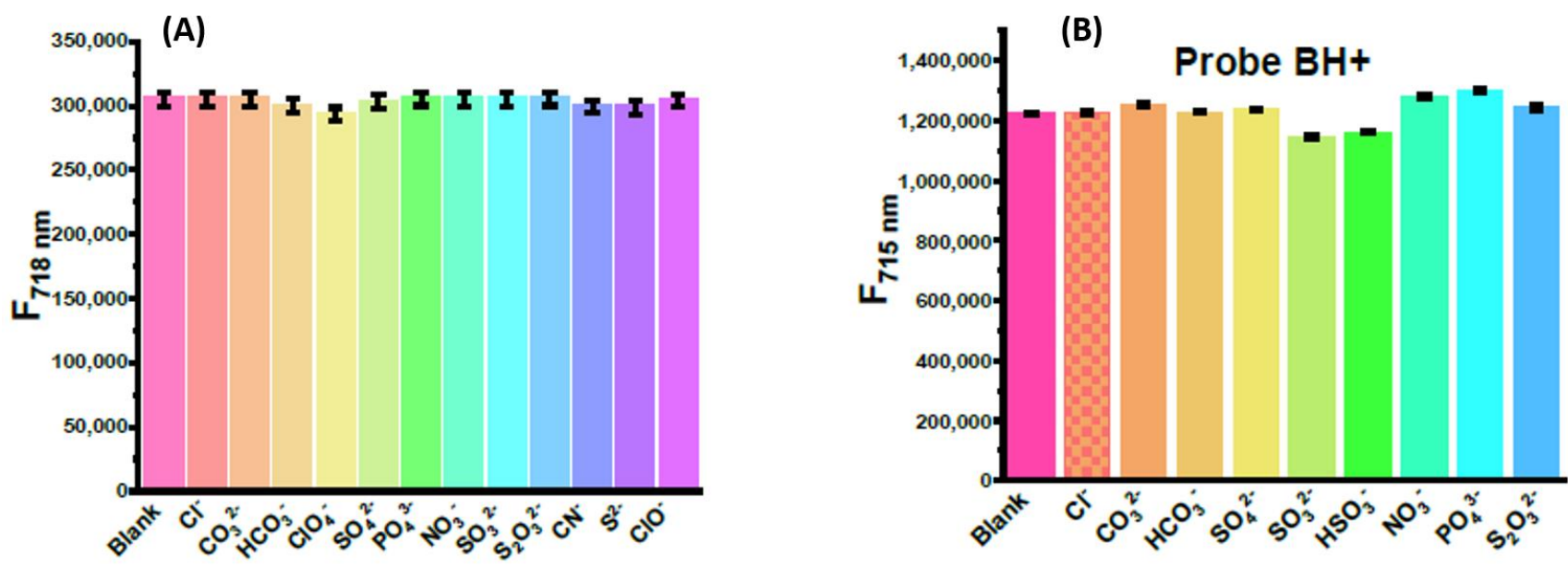

Figure 9. Fluorescence intensities of $10 \mu \mathrm{M}$ probes $\mathbf{A H}^{+}(\mathbf{A})$ and probe $\mathbf{B H}^{+}(\mathbf{B})$ in the absence and presence of different anions $(200 \mu \mathrm{M})$ in $\mathrm{pH} 7.4$ buffers under excitation at $635 \mathrm{~nm}$, respectively.
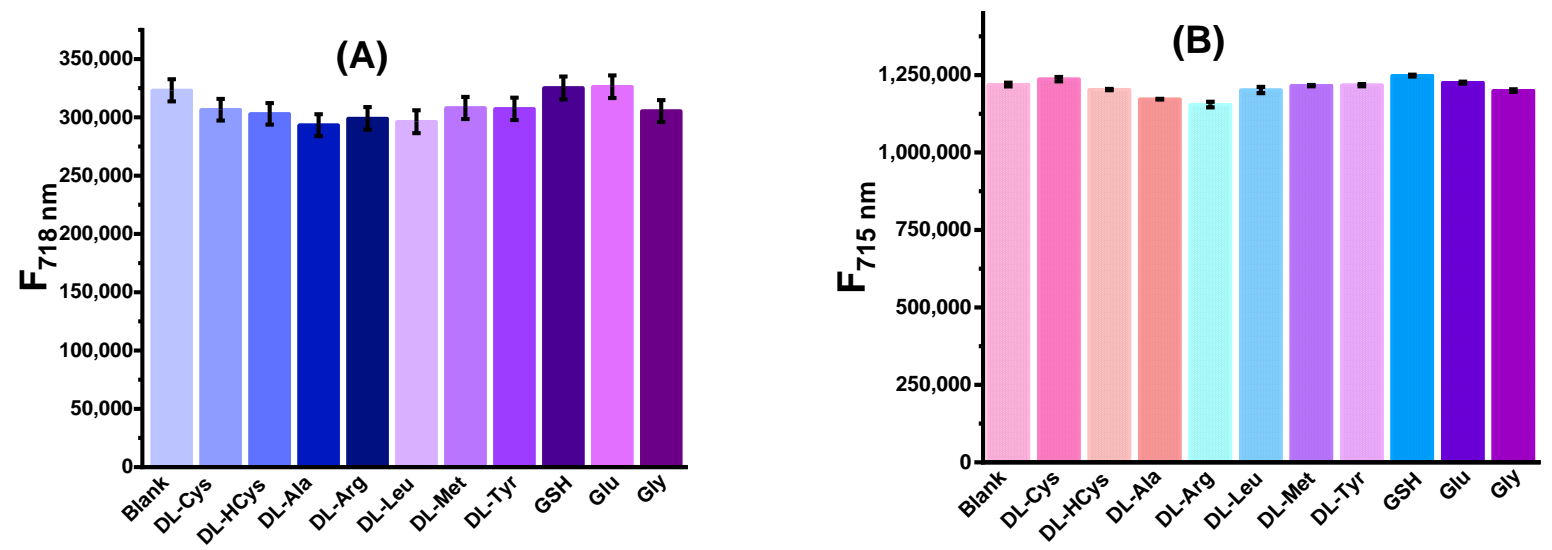

Figure 10. Fluorescence intensities of $10 \mu \mathrm{M}$ probes $\mathbf{A H}^{+}(\mathbf{A})$ and probe $\mathbf{B H}^{+}(\mathbf{B})$ in the absence and presence of different amino acids $(200 \mu \mathrm{M})$ in $\mathrm{pH} 7.4$ buffers under excitation at $635 \mathrm{~nm}$, respectively.

\subsection{Photostability of the Probes}

We then performed the photostability experiment of these two probes. As shown in Figure 11, the intensity of probes did not show significant changes either under an acid environment, at about $\mathrm{pH} 4.0$, or at neutral $\mathrm{pH} 7.0$, indicating that the probe shows excellent photostability (Figure 11).
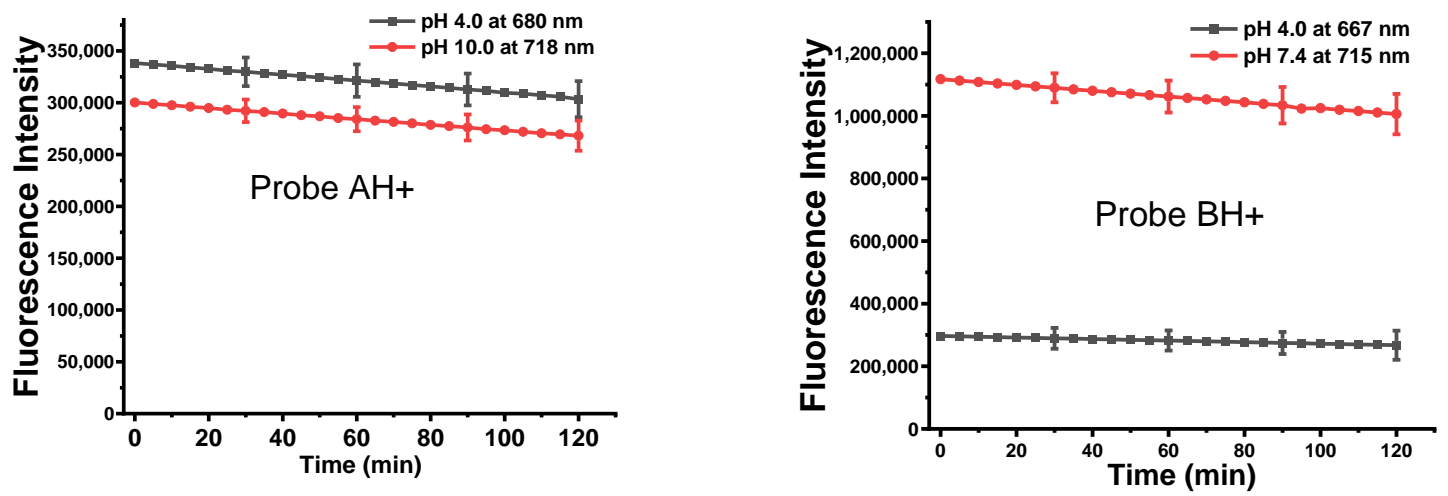

Figure 11. Photostability of $5 \mu \mathrm{M}$ fluorescent probe $\mathbf{A H}^{+}$and $\mathbf{B H}^{+}$at $\mathrm{pH} 4.0$ and $\mathrm{pH} 7.4$ buffer solutions containing $1.0 \%$ ethanol with three-repeated experiments every $30 \mathrm{~min}$ under continuous excitation at $635 \mathrm{~nm}$. 


\subsection{Cell Cytotoxicity}

We evaluated the cell cytotoxicity of the probes for their biocompatibility by MTT assay. The cytotoxicity of the probe increases slightly with the probe concentration with lower cell viability. High concentrations $(50 \mu \mathrm{M})$ of the probe do not cause considerable cytotoxicity because the cell viability is still higher than $91 \%$, indicating that the probe shows excellent biocompatibility and low toxicity (Figure 12). $\mathrm{IC}_{50}$ values of probes $\mathbf{A H}^{+}$ and $\mathbf{B H}^{+}$are $135 \mu \mathrm{M}$ and $155 \mu \mathrm{M}$, respectively, when the cell viability rate reaches $50 \%$ after incubation of HeLa cells with probe $\mathbf{A H}^{+}$or $\mathbf{B H}^{+}$.
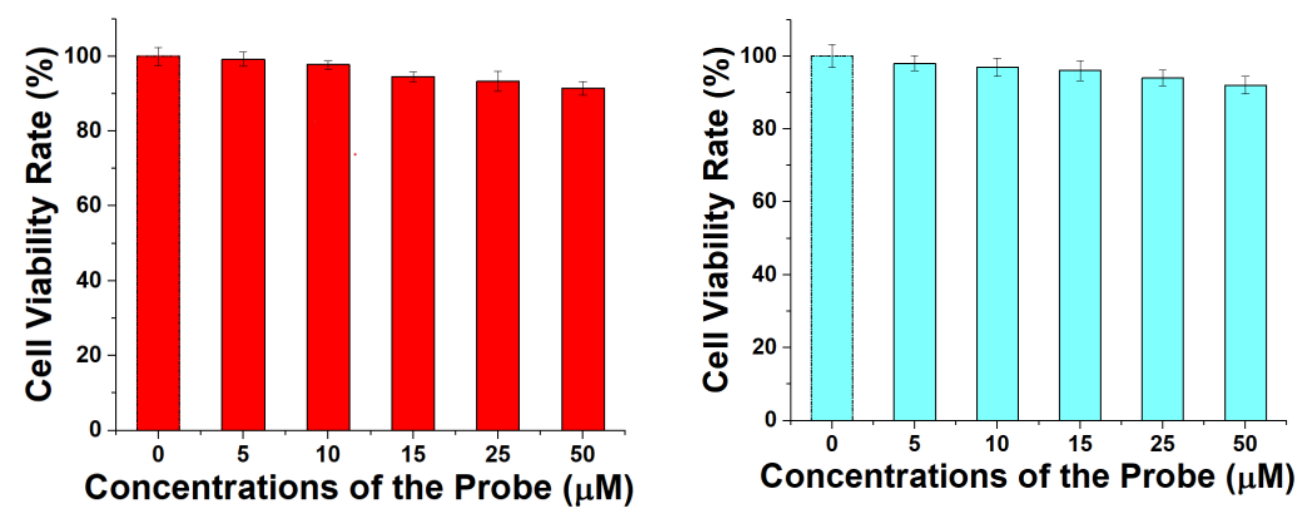

Figure 12. Cytotoxicity and cell proliferation effect of probes (left) and (right) was tested by MTT assay. The HeLa cells were incubated with different concentrations of the probe for $2 \mathrm{~h}$ for mitochondria staining.

\subsection{Analysis of Mitochondrial Localization for $\mathbf{A H}^{+}$and $\mathbf{B H}^{+}$Probes in Live Cells}

To assess the validity of our assumption that probes $\mathbf{A H}^{+}$and $\mathbf{B H}^{+}$can specifically accumulate inside of mitochondria [33,34], we conducted colocalization studies in live cells, using a commercial available mitochondria-specific dye, i.e., Mitoview Blue, for the control. As probes $\mathbf{A H}^{+}$and $\mathbf{B H}^{+}$exhibit near-infrared fluorescence $(>667 \mathrm{~nm})$, it is easy to distinguish their fluorescent signal from biological background fluorescence as that occurs at a lower wavelength (i.e., 400-500 nm). For live-cell imaging, HeLa cells were incubated with $\mathbf{A H}^{+} /$Mitoview Blue and $\mathbf{B H}^{+} /$Mitoview Blue mixtures. The dye-treated cells were further taken for confocal imaging. Imaging analysis has shown that both $\mathbf{A H}^{+}$and $\mathbf{B H}^{+}$ probes have effectively penetrated the cellular membrane and localized in the cytoplasm. $\mathbf{A H}^{+}$and $\mathbf{B H}^{+}$probes were visible using a $635 \mathrm{~nm}$ excitation $/ 700-750 \mathrm{~nm}$ emission channel (channel II, Figure 13). Mitoview Blue was visible in these cells under a $405 \mathrm{~nm}$ excitation and $425-475 \mathrm{~nm}$ emission (channel III, Figure 13). Colocalization analysis of the probes $\mathbf{A H}^{+}$and $\mathbf{B H}^{+}$with Mitoview Blue resulted in Pearson's correlation coefficient values of 0.924 and 0.955 , which confirms that the new probes are localized within mitochondria.

We further assessed whether the presence of the electrophilic formyl or dithioacetal groups contributes to the retention of these probes in mitochondria. It has been well established that the membrane potential is the driving force for the uptake of fluorescent lipophilic cations in mitochondria [35]. It has also been shown that ionophores can effectively prevent the uptake of such species [35]. Furthermore, changing the membrane potential has also been shown to promote the efflux of charge species from mitochondria [36]. On these bases, it is expected that changing the membrane potential in probe-treated HeLa cells would induce the efflux of fluorescent lipophilic cations from mitochondria. Therefore, we sought to alter the mitochondrial membrane potential to assess the retention of either probe $\mathrm{AH}^{+}$or $\mathbf{B H}^{+}$within the mitochondria. We used FCCP (carbonyl cyanide p-(tri-fluoromethoxy)phenyl-hydrazone)-the ionophore demonstrated to uncouple oxidative phosphorylation in mitochondria, disrupt the proton gradient along the inner mitochondrial membrane, and acidify mitochondria [35]. 


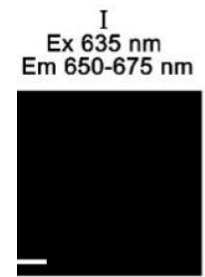

III
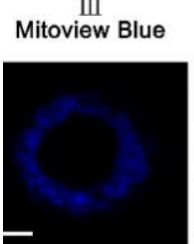

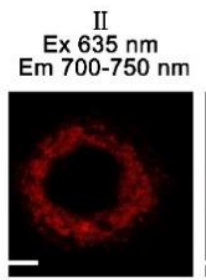

Merge of Intensity Correlationship III and III

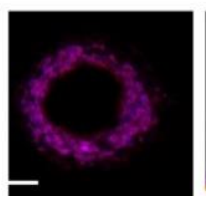

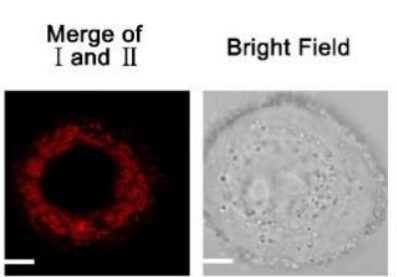

II and III

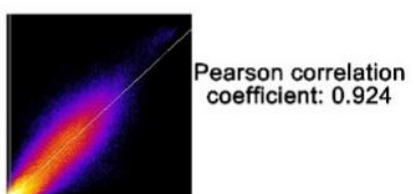

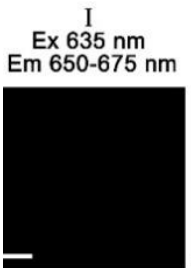

III
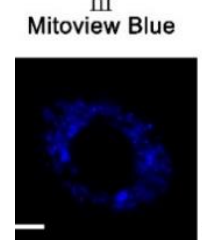

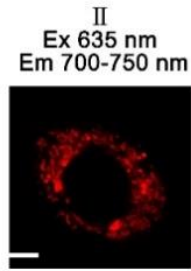

$\begin{array}{cc}\text { Merge of } & \text { Intensity Corelationship } \\ \text { II and III } & \text { II and III }\end{array}$

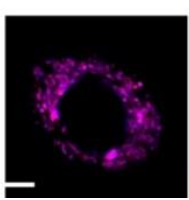

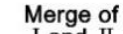

I and II Bright Field
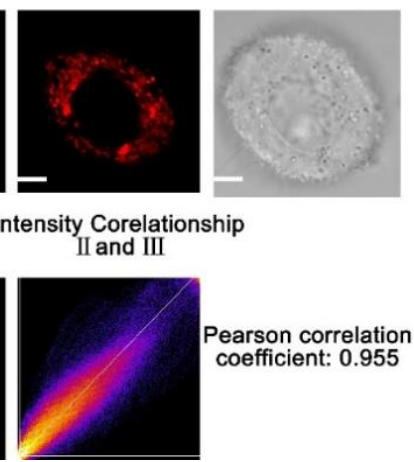

Figure 13. Fluorescence images of HeLa cells incubated with $10 \mu \mathrm{M}$ probes $\mathbf{A H}^{+}$(left), $\mathbf{B H}^{+}$(right), and $5.0 \mu \mathrm{M} \mathrm{Mitoview}$ Blue. The first and second channels in the fluorescence images were recorded from $650 \mathrm{~nm}$ to $675 \mathrm{~nm}$, and from $700 \mathrm{~nm}$ to $750 \mathrm{~nm}$ under excitation at $635 \mathrm{~nm}$, respectively. The third channel in the images was collected from $425 \mathrm{~nm}$ to $460 \mathrm{~nm}$ under excitation of $405 \mathrm{~nm}$. Scale bars: $10 \mu \mathrm{m}$. HeLa cells were incubated with $10 \mu \mathrm{M}$ probe $\mathbf{A H}^{+}$or $\mathbf{B H}^{+}$in media at $37{ }^{\circ} \mathrm{C}$ for 20 min. Live-cell images were obtained by an Olympus IX 81 confocal microscope.

HeLa cells were first incubated with $\mathbf{A H}^{+}$and $\mathbf{B H}^{+}$and then treated with FCCP (carbonyl cyanide p-(tri-fluoromethoxy)phenyl-hydrazone) [37-39]. After the subsequent treatments, we used fluorescence microscopy to assess the results (Figures 14 and 15). Before the FCCP treatment, only near-infrared fluorescence in channel II (700-750 nm) was observable for $\mathbf{A H}^{+}$and $\mathbf{B H}^{+}$probes, corresponding to the existence of these probes in a non-protonated state. After FCCP treatment, a new fluorescence signal became observable in channel I (650-675 nm). The intensity of this new signal increased as fluorescence in channel II decreased. The appearance of a new fluorescence signal appears to be informative of probe protonation and stabilization of more blue-shifted $\mathrm{AH}^{+}$or $\mathbf{B H}^{+}$and indicative of mitochondrial acidification. We also observed that FCCP appears to induce a background green fluorescence in cells (Figures 14 and 15). The green fluorescence co-localizes with the fluorescence induced by $\mathrm{AH}^{+}$and $\mathrm{BH}^{+}$probes, suggesting the same site accumulation. The observed lack of $\mathbf{A H}^{+}$or $\mathbf{B H}^{+}$diffusing from the mitochondria supports the idea that the introduced electrophilic formyl and dithioacetal moieties reacted and bonded with interstitial mitochondrial proteins for the observed mitochondrial retention.

\subsection{Assessing $\mathbf{A H}^{+}$and $\mathbf{B H}^{+}$as Intercellular $p H$ Sensors}

In order to demonstrate that our probes can respond to intracellular $\mathrm{pH}$ changes, we incubated HeLa cells with $\mathbf{A H}^{+}$and $\mathbf{B} \mathbf{H}^{+}$, adjusted intracellular $\mathrm{pH}$ to 9.0, 8.0, 7.5, $6.5,6.0$, and 5.0 by nigericin $\left(\mathrm{H}^{+} / \mathrm{K}^{+}\right.$ionophore) $[16,18,23,24,40-44]$, and collected cellular fluorescence in two channels from $650 \mathrm{~nm}$ to $657 \mathrm{~nm}$, and from $700 \mathrm{~nm}$ to $750 \mathrm{~nm}$ under excitation of $635 \mathrm{~nm}$. With the confocal fluorescence imaging (Figure 16), upon gradual decrease of intracellular $\mathrm{pH}$ from 9.0 to 5.0, we observed an expected gradual decrease in fluorescence in the channel II and gradual increase in fluorescence in the channel I (Figures 16 and 17). Merged images of channels I and II show color change from deep red to green, validating $\mathbf{A H}^{+}$and $\mathbf{B H}^{+}$as ratiometric reporters of intracellular $\mathrm{pH}$ changes (Figure 16). 


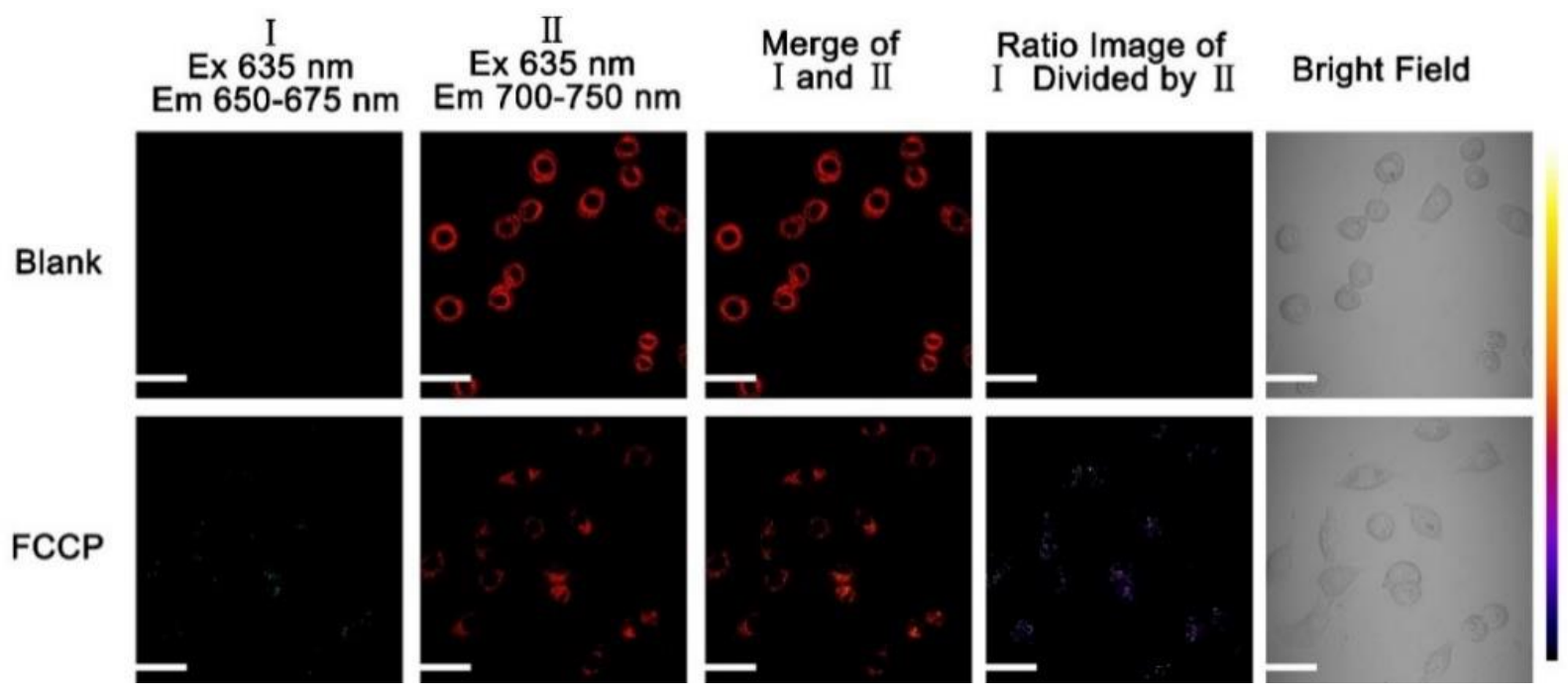

Figure 14. Fluorescence images of HeLa cells incubated with $10 \mu \mathrm{M}$ probes $\mathbf{A H}^{+}$before and after FCCP treatment. The first and second channels in the fluorescence images were recorded from $650 \mathrm{~nm}$ to $675 \mathrm{~nm}$, and from $700 \mathrm{~nm}$ to $750 \mathrm{~nm}$ under excitation at $635 \mathrm{~nm}$, respectively. Scale bars: $10 \mu \mathrm{m}$. HeLa cells were incubated with $10 \mu \mathrm{M}$ probe $\mathrm{AH}^{+}$for $20 \mathrm{~min}$, and further treated with $10 \mu \mathrm{M}$ FCCP in PBS $37^{\circ} \mathrm{C}$ for $20 \mathrm{~min}$. Live cell images were obtained by an Olympus IX 81 confocal microscope. ImageJ software was used to obtain ratiometric images. The software is free from https://imagej.nih.gov/ij/, 2 April 2021

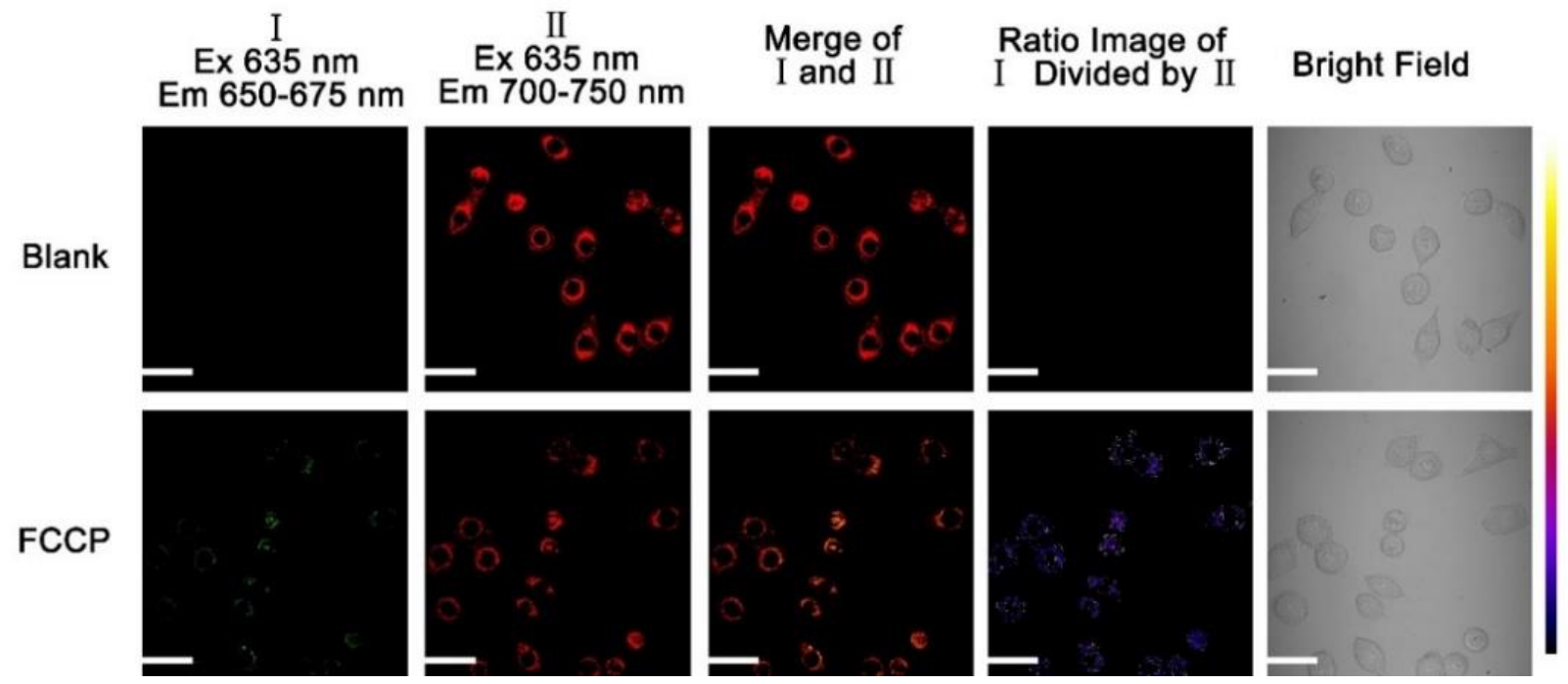

Figure 15. Fluorescence images of HeLa cells incubated with $10 \mu \mathrm{M}$ probes $\mathbf{B H}^{+}$before and after FCCP treatment. The first and second channels in the fluorescence images were recorded from $650 \mathrm{~nm}$ to $675 \mathrm{~nm}$, and from $700 \mathrm{~nm}$ to $750 \mathrm{~nm}$ under excitation at $635 \mathrm{~nm}$, respectively. Scale bars: $10 \mu \mathrm{m}$. HeLa cells were incubated with $10 \mu \mathrm{M}$ probe $\mathbf{B H}^{+}$for $20 \mathrm{~min}$, and further treated with $10 \mu \mathrm{M}$ FCCP in PBS at $37^{\circ} \mathrm{C}$ for $20 \mathrm{~min}$. Live cell images were obtained by an Olympus IX 81 confocal microscope. ImageJ software was used to obtain ratiometric images. The software is free from https://imagej.nih.gov/ij/, 2 April 2021. 


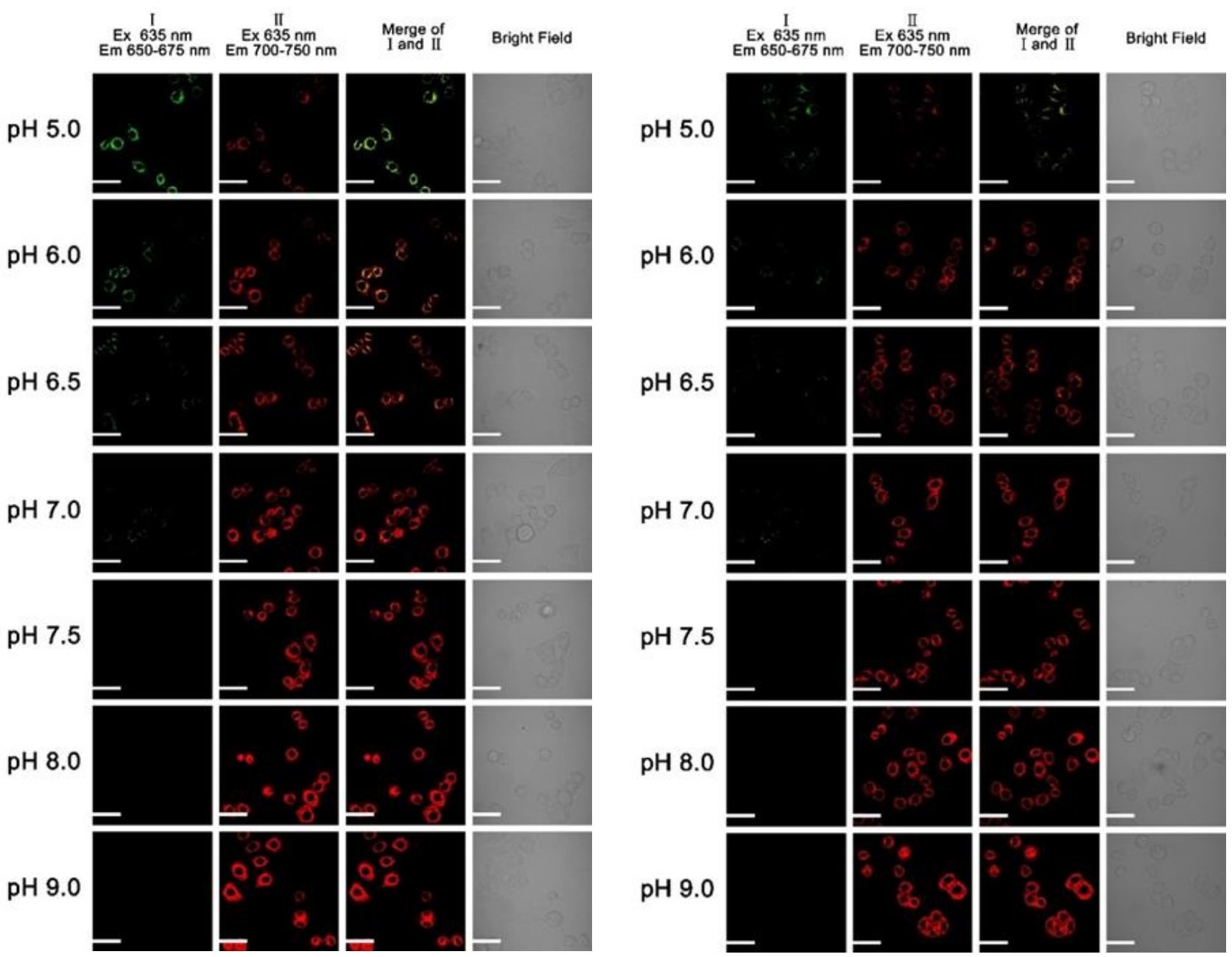

Figure 16. Fluorescence images of HeLa cells incubated with $10 \mu \mathrm{M}$ probes $\mathbf{A} \mathbf{H}^{+}$(left) and $\mathbf{B H}^{+}$(right) and nigericin to homogenize the intracellular $\mathrm{pH}$ of the cells with the surrounding medium at different $\mathrm{pH}$ values from 9.0, 8.0, 7.5, 6.5, 6.0, to 5.0. The first and second channels in the fluorescence images were recorded from $650 \mathrm{~nm}$ to $675 \mathrm{~nm}$, and from $700 \mathrm{~nm}$ to $750 \mathrm{~nm}$ under excitation at $635 \mathrm{~nm}$, respectively. HeLa cells were incubated with $10 \mu \mathrm{M}$ probe $\mathbf{A H}^{+}$or $\mathbf{B H}^{+}$for 20 min first, and then treated with $5 \mu \mathrm{g} / \mathrm{mL}$ nigericin in different $\mathrm{pH}$ buffer solutions at $37^{\circ} \mathrm{C}$ for $20 \mathrm{~min}$. Live cell images were obtained by an Olympus IX 81 confocal microscope.
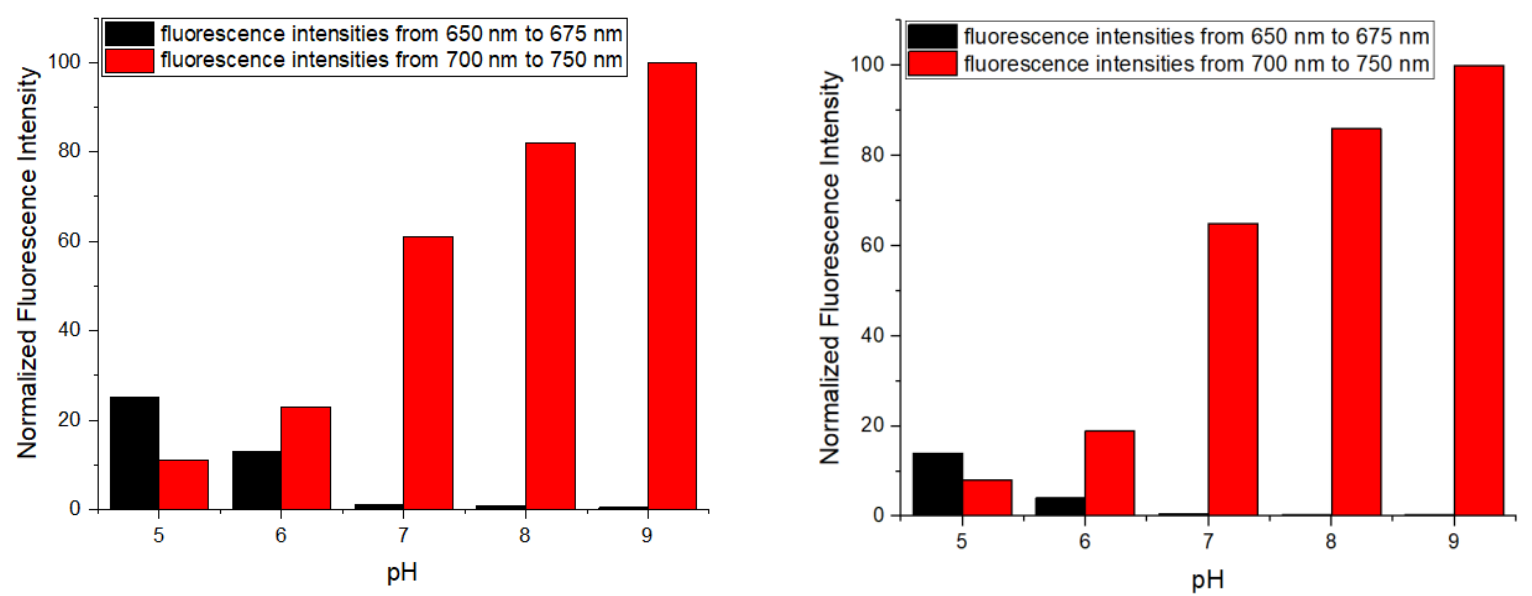

Figure 17. Fluorescence intensity of HeLa cells incubated with probes $\mathbf{A H}^{\mathbf{+}}$ (left) and $\mathbf{B H}^{+}$(right) obtained from Figure 16. 


\section{Experimental Section}

\subsection{Computational Analysis of Probes $A, \mathbf{A H}^{+}, B$, and $\mathbf{B H}^{+}$}

Models for probes $\mathbf{A}, \mathbf{A H}^{+}, \mathbf{B}$, and $\mathbf{B H}^{+}$were generated using previously published procedures [38] and conducted with density functional theory (DFT), using the APFD functional [45] and electron basis sets initially at the 6-31g(d) level to convergence in Gaussian 16 [46]. The results from this level were refined in a Polarizable Continuum Model (PCM) of water [47] with 6-311 ${ }^{+} \mathrm{g}(\mathrm{d})$ basis sets, and frequency calculations were conducted. Imaginary frequencies were not obtained. Seven excited states were assessed using TD-DFT optimizations [48] in a Polarizable Continuum Model (PCM) [48] in water with the 6-311 $\mathrm{g}(\mathrm{d})$ basis set. $\mathrm{pKa}$ calculations were conducted as described previously with the 6-311 ${ }^{+} \mathrm{g}(\mathrm{d})$ basis set with the optimized SMD implicit solvation method as described on AQUA-MER [26,27] on the converged models. pKa calculations were also conducted with the models enclosing one additional water molecule $\mathrm{H}$-bonded to the active $-\mathrm{OH}$ group [29]. Harmonic frequencies were derived in all cases to ensure that the structures obtained (atomic coordinates listed in Tables S9-S32) were minima on the potential energy surface and to obtain the required thermodynamic data for the $\mathrm{p} K_{\mathrm{a}}$ calculations. Results were interpreted using GaussView 6 [30] for all data and figures and are presented as Supporting Information.

\subsection{Reagents and Methods}

All solvents were purchased from Sigma-Aldrich (Saint Louis, MI, USA) and used directly. All solvents for spectroscopic studies were HPLC grade without fluorescent impurities and water was deionized. Dulbecco's modified Eagle's medium (DMEM) high glucose with stable glutamine with sodium pyruvate, Dulbecco's phosphate-buffered saline (DPBS), fetal bovine serum (FBS), trypsin $0.25 \%$-EDTA in HBSS, and penicillin-streptomycin were purchased from Aldrich-Sigma. Thiazolyl Blue Tetrazolium Bromide (MTT) was purchased from Sigma-Aldrich and used as received without further purification. ${ }^{1} \mathrm{H}$ and ${ }^{13} \mathrm{C}$ NMR spectra were recorded at room temperature with a Varian Unity Inova $400 \mathrm{MHz}$ spectrometer. All spectra of the probes were recorded in $\mathrm{pH}$ buffer containing 30\% $(v / v)$ ethanol. The following abbreviations are used to indicate the multiplicity: $\mathrm{s}$ - singlet; $\mathrm{d}$-doublet; $\mathrm{t}$-triplet; $\mathrm{q}$-quartet; $\mathrm{m}$-multiplet. The coupling constants are expressed in Hertz (Hz). Cary 60 UV-Vis spectrometer and Jobin Yvon Fluoromax-4 spectrofluorometer were used for absorption and fluorescence spectra, respectively. Confocal images were taken with Olympus FluoViewTM FV1000 using the FluoView software. Fluorescence imaging was done with an EVOS FLAuto inverted microscope.

\subsection{Cell Culture and Cytotoxicity Assay}

HeLa cells were cultured in the high glucose DMEM media supplemented with $10 \%$ FBS, $1 \%$ penicillin streptomycin in an incubator $\left(37^{\circ} \mathrm{C}, 5 \% \mathrm{CO}_{2}\right)[16,18,23,24,40-44]$. Cells were replenished with fresh medium every 2 days. The cellular metabolic activity was detected using colorimetric MTT assay, reflecting the loss of metabolic activity through the reduction of tetrazole (MTT) to formazan in mitochondria. For the assay, Hela cells were seeded in 96-well flat-bottomed plates at $1 \times 10^{4}$ cells per well and allowed to adhere for $24 \mathrm{~h}$ in the incubator $\left(37^{\circ} \mathrm{C}, 5 \% \mathrm{CO}_{2}\right)$. The medium was then removed, and a probe was added to the cells at different concentrations. The culture medium was added to the control group. Cells were then incubated $\left(37^{\circ} \mathrm{C}, 5 \% \mathrm{CO}_{2}\right)$ for $6 \mathrm{~h}$, the probe solution was removed, and cells were rinsed with DPBS gently. MTT reagent $(0.5 \mathrm{mg} / \mathrm{mL})$ in culture media was then added to the individual wells and incubated $\left(37^{\circ} \mathrm{C}, 5 \% \mathrm{CO}_{2}\right)$ for $3 \mathrm{~h}$. The MTT reagent was then removed from the cells, and DMSO $(100 \mu \mathrm{L} /$ well $)$ was added to dissolve formazan crystals. The plate was gently shaken using a mixer to solubilize the crystal for $30 \mathrm{~min}$. The absorbance was read at $550 \mathrm{~nm}$ using a Spectra Max i3x microplate reader. The data points from each concentration of probe were obtained from three wells and all experiments were repeated three times. 


\subsection{Cellular Imaging}

Hela cells were seeded on glass coverslips of a confocal dish without surface treatment and allowed to adhere for $24 \mathrm{~h}$. Subsequently, the medium was removed and the glass coverslips rinsed gently with DPBS. The cells were then stained with organelle trackers including commercial Mitoview Blue for $30 \mathrm{~min}$ in DPBS solution, before staining with the probe. The organelle markers are susceptible to potential oxidases in serum, therefore we used DPBS instead of a complete culture medium. Indeed, when we used a complete culture medium, mitochondria were not stained by the markers. After the cells were stained with one of the organelle trackers, the cells were then sequentially stained with the probe for $90 \mathrm{~min}$ in an incubator $\left(37^{\circ} \mathrm{C}, 5 \% \mathrm{CO}_{2}\right)$ and the fluorescence images were obtained by a confocal microscope every $10 \mathrm{~min}$. The cells were visualized simultaneously in each channel by a confocal fluorescence microscope, image analysis, and the data of colocalization between probe and organelle trackers was obtained by using ImageJ software.

\section{Conclusions}

Two ratiometric near-infrared fluorescent probes $\left(\mathbf{A H}^{+}\right.$and $\left.\mathbf{B H}^{+}\right)$based on hemicyanine dyes bearing thioether and formal residues have been developed for mitochondrial $\mathrm{pH}$ detection in live cells. The probes show reversible and ratiometric fluorescent responses to $\mathrm{pH}$ changes based on the protonation and deprotonation of a hydroxy group in hemicyanine dyes. Probes $\mathbf{A H}^{+}$and $\mathbf{B} \mathbf{H}^{+}$possessed experimental $\mathrm{p} K_{\mathrm{a}}$ values of 6.85 and 6.49 respectively, which are close to calculated $\mathrm{p} K_{\mathrm{a}}$ values of 7.33 and 6.14 for $\mathbf{A H}^{+}$and $\mathbf{B H}^{+}$.

Supplementary Materials: The following are available online. Results from the theoretical calculations for all probes including the pKa calculations, ${ }^{1} \mathrm{H}$ and ${ }^{13} \mathrm{C}$ NMR and high-resolution mass spectra for probes $\mathbf{A H}^{+}$and $\mathbf{B H}^{+}$, and fluorescence measurements of the probes with added cations and anions.

Author Contributions: Conceptualization, H.L., R.L.L. and M.T.; methodology, Y.Y., Y.Z. and S.X.; validation, T.V.; investigation, Y.Y., Y.Z., S.X., S.W., T.V.; resources, H.L.; writing-original draft preparation, H.L.; writing — review and editing, M.T. and R.L.L.; visualization, S.X.; supervision, H.L.; funding acquisition, H.L. All authors have read and agreed to the published version of the manuscript.

Funding: This work was supported by the National Institute of General Medical Sciences of the National Institutes of Health under Award Numbers R15GM114751 and 2R15GM114751-02 (for H.Y. Liu).

Institutional Review Board Statement: Not applicable.

Informed Consent Statement: Not applicable.

Data Availability Statement: Not applicable.

Acknowledgments: We greatly appreciate financial support of this research work by the National Institute of General Medical Sciences of the National Institutes of Health under Award Numbers R15GM114751 and 2R15GM114751-02 (for H.Y. Liu). The calculations of the fluorescent probe were conducted by using a high-performance computing infrastructure at Michigan Technological University.

Conflicts of Interest: The authors declare no conflict of interest.

Sample Availability: Samples of probes $\mathrm{AH}^{+}$and $\mathrm{BH}^{+}$are available from the authors.

\section{References}

1. Javadov, S.; Kozlov, A.V.; Camara, A.K.S. Mitochondria in Health and Diseases. Cells 2020, 9, 5. [CrossRef]

2. Annesley, S.J.; Fisher, P.R. Mitochondria in Health and Disease. Cells 2019, 8, 7. [CrossRef] [PubMed]

3. Dai, J.N.; Ma, C.G.; Zhang, P.; Fu, Y.Q.; Shen, B.X. Recent progress in the development of fluorescent probes for detection of biothiols. Dyes Pigment. 2020, 177, 108321. [CrossRef]

4. Wu, L.L.; Huang, C.S.; Emery, B.; Sedgwick, A.C.; Bull, S.D.; He, X.P.; Tian, H.; Yoon, J.; Sessler, J.L.; James, T.D. Forster resonance energy transfer (FRET)-based small-molecule sensors and imaging agents. Chem. Soc. Rev. 2020, 49, 5110-5139. [CrossRef] 
5. Zielonka, J.; Joseph, J.; Sikora, A.; Hardy, M.; Ouari, O.; Vasquez-Vivar, J.; Cheng, G.; Lopez, M.; Kalyanaraman, B. MitochondriaTargeted Triphenylphosphonium-Based Compounds: Syntheses, Mechanisms of Action, and Therapeutic and Diagnostic Applications. Chem. Rev. 2017, 117, 10043-10120. [CrossRef] [PubMed]

6. Zhu, H.; Fan, J.L.; Du, J.J.; Peng, X.J. Fluorescent Probes for Sensing and Imaging within Specific Cellular Organelles. Acc. Chem. Res. 2016, 49, 2115-2126. [CrossRef] [PubMed]

7. Hou, J.T.; Ren, W.X.; Li, K.; Seo, J.; Sharma, A.; Yu, X.Q.; Kim, J.S. Fluorescent bioimaging of pH: From design to applications. Chem. Soc. Rev. 2017, 46, 2076-2090. [CrossRef]

8. Yue, Y.K.; Huo, F.J.; Lee, S.; Yin, C.X.; Yoon, J. A review: The trend of progress about pH probes in cell application in recent years. Analyst 2017, 142, 30-41. [CrossRef]

9. Yin, J.; Hu, Y.; Yoon, J. Fluorescent probes and bioimaging: Alkali metals, alkaline earth metals and pH. Chem. Soc. Rev. 2015, 44, 4619-4644. [CrossRef]

10. Liu, Y.C.; Teng, L.L.; Chen, L.L.; Ma, H.C.; Liu, H.W.; Zhang, X.B. Engineering of a near-infrared fluorescent probe for real-time simultaneous visualization of intracellular hypoxia and induced mitophagy. Chem. Sci. 2018, 9, 5347-5353. [CrossRef]

11. Shi, X.H.; Jung, Y.N.; Lin, L.J.; Liu, C.; Wu, C.; Cann, I.K.O.; Ha, T. Quantitative Fluorescent Labeling of Aldehyde-Tagged Proteins for Single-Molecule Imaging. Biophys. J. 2012, 102, 581A. [CrossRef]

12. Song, Y.N.; Xiong, F.; Peng, J.Z.; Fung, Y.M.E.; Huang, Y.R.; Li, X.Y. Introducing aldehyde functionality to proteins using ligand-directed affinity labeling. Chem. Commun. 2020, 56, 6134-6137. [CrossRef]

13. Wu, P.; Shui, W.Q.; Carlson, B.L.; Hu, N.; Rabuka, D.; Lee, J.; Bertozzi, C.R. Site-specific chemical modification of recombinant proteins produced in mammalian cells by using the genetically encoded aldehyde tag. Proc. Natl. Acad. Sci. USA 2009, 106, 3000-3005. [CrossRef]

14. Purushottam, L.; Adusumalli, S.R.; Singh, U.; Unnikrishnan, V.B.; Rawale, D.G.; Gujrati, M.; Mishra, R.K.; Rai, V. Single-site glycine-specific labeling of proteins. Nat. Commun. 2019, 10, 1-9. [CrossRef]

15. Boutureira, O.; Bernardes, G.J.L. Advances in Chemical Protein Modification. Chem. Rev. 2015, 115, 2174-2195. [CrossRef] [PubMed]

16. Xia, S.A.; Wang, J.B.; Zhang, Y.B.; Whisman, N.; Bi, J.H.; Steenwinkel, T.E.; Wan, S.L.; Medford, J.; Tajiri, M.; Luck, R.L.; et al Ratiometric fluorescent probes based on through-bond energy transfer of cyanine donors to near-infrared hemicyanine acceptors for mitochondrial $\mathrm{pH}$ detection and monitoring of mitophagy. J. Mater. Chem. B 2020, 8, 1603-1615. [CrossRef]

17. Li, X.Y.; Hu, Y.M.; Li, X.H.; Ma, H.M. Mitochondria-Immobilized Near-Infrared Ratiometric Fluorescent pH Probe To Evaluate Cellular Mitophagy. Anal. Chem. 2019, 91, 11409-11416. [CrossRef] [PubMed]

18. Xiao, H.B.; Dong, Y.Q.; Zhou, J.; Zhou, Z.Y.; Wu, X.Z.; Wang, R.Z.; Miao, Z.C.; Liu, Y.Y.; Zhuo, S.P. Monitoring mitochondrial pH with a hemicyanine-based ratiometric fluorescent probe. Analyst 2019, 144, 3422-3427. [CrossRef]

19. Ning, P.; Hou, L.L.; Feng, Y.; Xu, G.Y.; Bai, Y.Y.; Yu, H.Z.; Meng, X.M. Real-time visualization of autophagy by monitoring the fluctuation of lysosomal $\mathrm{pH}$ with a ratiometric two-photon fluorescent probe. Chem. Commun. 2019, 55, 1782-1785. [CrossRef] [PubMed]

20. Chang, M.J.; Kim, K.; Park, K.S.; Kang, J.S.; Lim, C.S.; Kim, H.M.; Kang, C.; Lee, M.H. High-depth fluorescence imaging using a two-photon FRET system for mitochondrial $\mathrm{pH}$ in live cells and tissues. Chem. Commun. 2018, 54, 13531-13534. [CrossRef]

21. Sarkar, A.R.; Heo, C.H.; Xu, L.; Lee, H.W.; Si, H.Y.; Byun, J.W.; Kim, H.M. A ratiometric two-photon probe for quantitative imaging of mitochondrial $\mathrm{pH}$ values. Chem. Sci. 2016, 7, 766-773. [CrossRef]

22. Chen, Y.C.; Zhu, C.C.; Cen, J.J.; Bai, Y.; He, W.J.; Guo, Z.J. Ratiometric detection of pH fluctuation in mitochondria with a new fluorescein/cyanine hybrid sensor. Chem. Sci. 2015, 6, 3187-3194. [CrossRef]

23. Wu, M.Y.; Li, K.; Liu, Y.H.; Yu, K.K.; Xie, Y.M.; Zhou, X.D.; Yu, X.Q. Mitochondria-targeted ratiometric fluorescent probe for real time monitoring of $\mathrm{pH}$ in living cells. Biomaterials 2015, 53, 669-678. [CrossRef]

24. Zhang, Y.B.; Xia, S.; Mikesell, L.; Whisman, N.; Fang, M.X.; Steenwinkel, T.E.; Chen, K.; Luck, R.L.; Werner, T.; Liu, H.Y. Near-Infrared Hybrid Rhodol Dyes with Spiropyran Switches for Sensitive Ratiometric Sensing of pH Changes in Mitochondria and Drosophila melanogaster First-Instar Larvae. ACS Appl. Bio Mater. 2019, 2, 4986-4997. [CrossRef]

25. Adamo, C.; Jacquemin, D. The calculations of excited-state properties with Time-Dependent Density Functional Theory. Chem. Soc. Rev. 2013, 42, 845-856. [CrossRef] [PubMed]

26. Lian, P.; Guo, L.; Devarajan, D.; Parks, J.M.; Painter, S.L.; Brooks, S.C.; Smith, J.C. The AQUA-MER databases and aqueous speciation server: A web resource for multiscale modeling of mercury speciation. J. Comput. Chem. 2020, 41, 147-155. [CrossRef] [PubMed]

27. Lian, P.; Johnston, R.C.; Parks, J.M.; Smith, J.C. Quantum Chemical Calculation of pKa's of Environmentally Relevant Functional Groups: Carboxylic Acids, Amines, and Thiols in Aqueous Solution. J. Phys. Chem. A 2018, 122, 4366-4374. [CrossRef] [PubMed]

28. Scalmani, G.; Frisch, M.J. Continuous surface charge polarizable continuum models of solvation. I. General formalism. J. Chem. Phys. 2010, 132, 114110. [CrossRef]

29. Thapa, B.; Schlegel, H.B. Improved pKa Prediction of Substituted Alcohols, Phenols, and Hydroperoxides in Aqueous Medium Using Density Functional Theory and a Cluster-Continuum Solvation Model. J. Phys. Chem. A 2017, 121, 4698-4706. [CrossRef]

30. Dennington, R.; Keith, T.A.; Millam, J.M. GaussView, Version 6.0.16; Semichem Inc.: Shawnee Mission, KS, USA, 2016.

31. Tomasi, J.; Mennucci, B.; Cammi, R. Quantum Mechanical Continuum Solvation Models. Chem. Rev. 2005, 105, 2999-3094. [CrossRef] 
32. Bondi, A. van der Waals Volumes and Radii. J. Phys. Chem. 1964, 68, 441-451. [CrossRef]

33. Rhee, W.J.; Bao, G. Slow non-specific accumulation of 2'-deoxy and 2'-O-methyl oligonucleotide probes at mitochondria in live cells. Nucleic Acids Res. 2010, 38, e109. [CrossRef]

34. Jiang, Z.W.; Liu, H.X.; He, H.; Yadava, N.; Chambers, J.J.; Thayumanavan, S. Anionic Polymers Promote Mitochondrial Targeting of Delocalized Lipophilic Cations. Bioconjug. Chem. 2020, 31, 1344-1353. [CrossRef]

35. Chen, L.B. Mitochondrial membrane potential in living cells. Annu. Rev. Cell Biol. 1988, 4, 155-181. [CrossRef]

36. Poburko, D.; Santo-Domingo, J.; Demaurex, N. Dynamic Regulation of the Mitochondrial Proton Gradient during Cytosolic Calcium Elevations. J. Biol. Chem. 2011, 286, 11672-11684. [CrossRef]

37. Liu, Y.; Zhou, J.; Wang, L.L.; Hu, X.X.; Liu, X.J.; Liu, M.R.; Cao, Z.H.; Shangguan, D.H.; Tan, W.H. A Cyanine Dye to Probe Mitophagy: Simultaneous Detection of Mitochondria and Autolysosomes in Live Cells. J. Am. Chem. Soc. 2016, 138, 12368-12374. [CrossRef]

38. Zhang, Y.B.; Bi, J.H.; Xia, S.; Mazi, W.; Wan, S.L.; Mikesell, L.; Luck, R.L.; Liu, H.Y. A Near-Infrared Fluorescent Probe Based on a FRET Rhodamine Donor Linked to a Cyanine Acceptor for Sensitive Detection of Intracellular pH Alternations. Molecules 2018, 23, 2679. [CrossRef]

39. Mazi, W.; Yan, Y.N.; Zhang, Y.B.; Xia, S.; Wan, S.L.; Tajiri, M.; Luck, R.L.; Liu, H.Y. A near-infrared fluorescent probe based on a hemicyanine dye with an oxazolidine switch for mitochondrial pH detection. J. Mater. Chem. B 2021, 9, 857-863. [CrossRef]

40. Xia, S.; Wang, J.B.; Bi, J.H.; Wang, X.; Fang, M.X.; Phillips, T.; May, A.; Conner, N.; Tanasova, M.; Luo, F.T.; et al. Fluorescent probes based on pi-conjugation modulation between hemicyanine and coumarin moieties for ratiometric detection of $\mathrm{pH}$ changes in live cells with visible and near-infrared channels. Sens. Actuator B-Chem. 2018, 265, 699-708. [CrossRef]

41. Wang, J.B.; Xia, S.; Bi, J.H.; Zhang, Y.B.; Fang, M.X.; Luck, R.L.; Zeng, Y.B.; Chen, T.H.; Lee, H.M.; Liu, H.Y. Near-infrared fluorescent probes based on TBET and FRET rhodamine acceptors with different $\mathrm{pK}(\mathrm{a})$ values for sensitive ratiometric visualization of pH changes in live cells. J. Mater. Chem. B 2019, 7, 198-209. [CrossRef]

42. Xia, S.; Fang, M.X.; Wang, J.B.; Bi, J.H.; Mazi, W.; Zhang, Y.B.; Luck, R.L.; Liu, H.Y. Near-infrared fluorescent probes with BODIPY donors and rhodamine and merocyanine acceptors for ratiometric determination of lysosomal $\mathrm{pH}$ variance. Sens. Actuator B-Chem. 2019, 294, 1-13. [CrossRef] [PubMed]

43. Li, H.X.; Dong, H.; Yu, M.M.; Liu, C.X.; Li, Z.X.; Wei, L.H.; Sun, L.D.; Zhang, H.Y. NIR Ratiometric Luminescence Detection of pH Fluctuation in Living Cells with Hemicyanine Derivative-Assembled Upconversion Nanophosphors. Anal. Chem. 2017, 89, 8863-8869. [CrossRef]

44. Wang, J.B.; Xia, S.; Bi, J.H.; Fang, M.X.; Mazi, W.F.; Zhang, Y.B.; Conner, N.; Luo, F.T.; Lu, H.P.; Liu, H.Y. Ratiometric Near-Infrared Fluorescent Probes Based On Through Bond Energy Transfer and pi-Conjugation Modulation between Tetraphenylethene and Hemicyanine Moieties for Sensitive Detection of pH Changes in Live Cells. Bioconjug. Chem. 2018, 29, 1406-1418. [CrossRef] [PubMed]

45. Austin, A.; Petersson, G.A.; Frisch, M.J.; Dobek, F.J.; Scalmani, G.; Throssell, K. A Density Functional with Spherical Atom Dispersion Terms. J. Chem. Theory Comput. 2012, 8, 4989-5007. [CrossRef] [PubMed]

46. Frisch, M.J.; Trucks, G.W.; Schlegel, H.B.; Scuseria, G.E.; Robb, M.A.; Cheeseman, J.R.; Scalmani, G.; Barone, V.; Mennucci, B.; Petersson, G.A.; et al. Gaussian 16; Gaussian, Inc.: Wallingford, CT, USA, 2016.

47. Cances, E.; Mennucci, B.; Tomasi, J. A new integral equation formalism for the polarizable continuum model: Theoretical background and applications to isotropic and anisotropic dielectrics. J. Chem. Phys. 1997, 107, 3032-3041. [CrossRef]

48. Casida, M.E.; Jamorski, C.; Casida, K.C.; Salahub, D.R. Molecular excitation energies to high-lying bound states from timedependent density-functional response theory: Characterization and correction of the time-dependent local density approximation ionization threshold. J. Chem. Phys. 1998, 108, 4439-4449. [CrossRef] 